\title{
Overcoming Barriers to Residential Conservation: Do Energy Audits Help?
}

December 1982

Prepared for the U.S. Department of Energy under Contract DE-AC06-76RLO 1830

Pacific Northwest Laboratory Operated for the U.S. Department of Energy by Battelle Memorial Institute 


\section{DISCLAIMER}

This report was prepared as an account of work sponsored by an agency of the United States Government. Neither the United States Government nor any agency thereof, nor any of their employees, makes any warranty, express or implied, or assumes any legal liability or responsibility for the accuracy, completeness, or usefulness of any information, apparatus, product, or process disclosed, or represents that its use would not infringe privately owned rights. Reference herein to any specific commercial product, process, or service by trade name, trademark, manufacturer, or otherwise, does not necessarily constitute or imply its endorsement, recommendation, or favoring by the United States Government or any agency thereof. The views and opinions of authors expressed herein do not necessarily state or reflect those of the United States Government or any agency thereof.

PACIFIC NORTHWEST LABORATORY operated by

BATTELLE

for the

UNITED STATES DEPARTMENT OF ENERGY under Contract DE-AC06-76RLO 1830

Printed in the United States of America Available from

National Technical Information Service United States Department of Commerce 5285 Port Royal Road Springfield, Virginia 22151

NTIS Price Codes

Microfiche A01

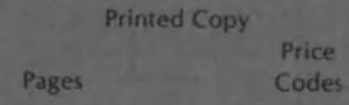

001-025

026-050

Codes

051-075

$\mathrm{A} 02$

$076-100$

$101-125$

$126-150$

$151-175$

$176-200$

$201-225$

226-250

251-275

A04

A05

A06

A07

A 08

A 09

A010

A011

A 012

A013 
PNL -4552

UC- 95

OVERCOMING BARRIERS TO RESIDENTIAL

CONSERVATION: DO ENERGY AUDITS HELP?

W. L. Hoffman, Principal Investigator (a)

A. L. Nieves, Project Manager

December 1982

Prepared for

the U.S. Department of Energy

under Contract DE-ACO6-76RL O 1830

Pac ific Northwest Laboratory

Richland, Washington 99352

(a) Now with the National Institute for Social and Economic Research, Boulder, Colorado 


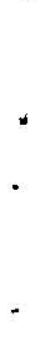




\section{Acknowledgements}

We wish to thank the Potomac Electric Power Company, The Washington Gas Company and the Public Service Company of Colorado who provided us with information and assistance while performing Home Energy Audits for households in our study sample. Thanks also to James Zais of the Urban Institute for his helpful comments.

Preparation of this report was accomplished while the principal investigator was at the Urban Institute, Washington, D.C. Financial support for data collection on which the present analys is was based was partially provided by a grant (\#8150284) from the Ford Foundation. 


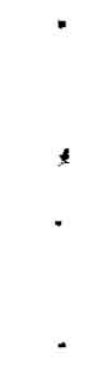


CONTENTS

ACKNOWLEDGMENT - -

INTRODUCTION AND SUMMARY - 1

Overview -

Expected Audit Program Effects - 2

Organization of This Report and Specific Findings - 5

Strengths and Limitations of The Study - 7

I. HOUSEHOLD EVALUATION OF THE AUDIT - 11

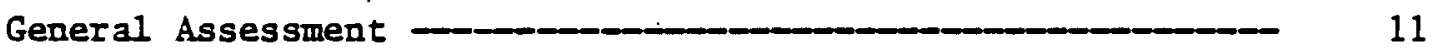

Preference For Additional Ut1lity Company Assistance - 15

Actions Attriduted to The Audit 19

Summary of Eousehold Evaluations 21

II. EFFECTIVENESS OF THE AUDIT IN STIMULATING

CONSERVATION ACTION - 24

Comparison of Reported Acts - 24

Possible Explanation For Divergence of Findings - 29

Audit Effects and Previous1y Planned Activities - 32

Who Responds to Audits 36

III. EFFECT OF AUDITS ON HOUSEHOLDS CONSERVATION KNOWLEDGE AND CHOICE OF RETROFIT INVESTMENT -

Changes in Household Awareness of Attractive Options - $\quad 40$

Attractiveness of Efficiency Improvements
Completed or Planned

IV. CONCLUDING COMMENTS - 50

APPENDIX A: SAMPLE CRARACTERISTICS - 52

Baseline Sample - 53

Follow-up Sample - 54

Post-Audit Control Sample - 58

Audited Samples - 63

Summary of Sample Blas Effects of Study Results - 67 
.

.

. 
INTRODUCTION AND SUMMARY

Overview

This report presents the results of phase two analysis in a study of ways to overcome barriers to increased residential energy conservation.1 The principal focus is on the effects of energy audits-as conducted by utility companies under the Residential Conservation Service (RCS) format-on the pace and choice of household investment in energy-saving improvements in the home. Three types of evaluation are performed.

- An evaluation based on the household's assessment of the usefulness of the audit which was provided for their home.

- A comparison of the number and types of recent conservation actions among audited and unaudited samples of households.

- An assessment of the audit's effect on household knowledge about the economically attractive options for their home and on the choice of recent improvements.

The research plan for this study is based on quasi-experimental

design involving three sources of data.

- Baseline surveys of households which were conducted in selected neighborhood areas of Washington, D.C. and Denver, Colorado, during the Spring and Fall of 1981 respectively.

1. Initial support for this project and baseline data collection was supported by a special grant from the Ford Foundation. Special analysis of elderly households' conservation effort was supported by the Environmental Protection Agency and the Council on Environmental Quality. Two reports were prepared by the author under previous funding: The Residential Conservation Gap Study: Purpose, Research Design and Data Collection Report \$3030-01, October 1981; and The Elderly and the Conservation Gap, Report \#3030-02, December 1981. The current project is supported by Battelle Memorial Institute Pacific Northwest Laboratories. The report on phase one analysis for the current project is: Barriers to Household Investment In Residential Conservation: Preliminary Assessment, Report 非3110-01, March 1982 . 
- An on-site energy audit performed by local utility companies in cooperation with The Urban Institute for approximately 25 percent of surveyed units shortly after the baseline survey.

- A follow-up telephone interview in January 1982 with both audited and unaudited households from the original samples and with small control samples ( 100 households) at each site who had not been previously contacted.

Expected Audit Program Effects

Since 1978, federal law has required that most large fuel or power supply utilities make available an on-site energy audit for the homes of their residential customers. The audit is one component of a larger package of conservation services embodied in regulation promulgated for the Residential Conservation Service (RCS) program. While final status of the RCS program is not settled under current administration and state policies, audits have now been offered by most utilities in the nation. As implied by supporting studies for the RCS regulations, audits are expected to stimulate additional investment in weatherization and related energy efficiency improvements in the nation's residential stock. 1 While estimates varied, a range of from 40 to 75 percent of audited households were expected to make major energy saving improvements because of the audit.

The stimulative effect of the audit was expected to derive from two sources: heightened interest and awareness of low-cost practices and options based on contact with the auditor and more rapid and efficient retrofit based on detailed analysis of options. Household contact with

1. These figures applied to all energy-saving improvements for the household which would have paybacks of six years or less. See: Residential Conservation Service: Regulatory Analysis U.S. Department of Energy, October 1979, (DOE/CS-00104/1) p. 2-255 and elsewhere. 
a trained energy specialist would provide residents the opportunity to ask questions about conservation materials, appropriate applications, choice between contractor or self-installation, and simply to become more familiar with aspects of their structure which were energy inefficient. The detailed report which ensued from the audit would provide item-by-item cost and savings estimates that could be expected from major improvements. This information was difficult and/or time consuming for the resident to assemble without the assistance of the utility. In addition, cost and savings estimates would be summarily compared in terms of expected payback-the period of time it would take to recoup initial costs through lowered utility or fuel bills. Choices between improvements to attic insulation or the addition of storm windows, for instance, or between heating system improvements and extensive caulking and weatherstripping could be based on the most attractive return to investment represented by the payback estimates.

Because it was known that many units had several economically attractive options for retrofit during a period of energy price increases, the audit could also be viewed as a vehicle for overcoming imperfections in the market for energy services--primarily those due to high information costs and low familiarity with many new conservation materials, suppliers, and contractors. Within the context of this study, audits are assessed from this perspective as vehicles for overcoming barriers to apparent economically attractive retrofit investment opportunities.

There have been several evaluations of the impact of utility audits but both program variations and the design of the evaluation studies 
have made it difficult to formulate a firm consensus on audit impact. A systematic review of the available evidence performed by others suggests that audit have been limited by identifiable impacts on the rate of conservation investment. 1

There are three tentative summary findings in previous reviews.

- Attitudes toward audits from households who have received them are extremely favorable.

- Overall, audits tend to increase the number of conservation actions.

- Audits tend to result in more low-cost actions rather than high-cost actions.

The findings of this study are generally consistent with the summary assessments embodied in previous program reviews: audits do increase the rate of activity and are favorably received. However, our analysis further suggests that while the audit effects are identifiable with respect to activity, these impacts are very small. Also, we find that household knowledge about appropriate options and choice of investment is not significantly affected by the audit, suggesting that the detailed payback analysis provided by Class $A$ audits are of little use to most households. A more detailed review of our findings as they are presented in this report is provided below.

1. A good summary review of programs is provided by Linda Berry and associates at the Oak Ridge National Laboratory. Review of Evaluations Utility Home Audit Programs (ORNL/CON-58), March 1981. This review is the most careful and systematic analysis based on published reports. Numerous other reviews have relied on impressionistic evidence gathered from discussions with utility personnel whose knowledge and use of systematic evaluation procedures has seemed to vary widely. 
Organization of This Report and Specific Findings

The first section of this report provides information on household assessment of the audit and the level of interest in other conservation assistance which utilities might provide.

- Audits are viewed as worthwhile, accurate, and informative by the overwhelming majority of households who received them, although there are notable site differences in these general assessments.

- The most useful aspects of the audit mentioned by households are "low-cost tips" provided at time of credit and "identification of specific improvements" that could be made to save energy.

- Ten percent of audited households at each site report that the most useful information in the audit was confirmation that the home was already well weatherized.

- The detailed information on costs of conservation items and estimates of annual savings from various options were rarely mentioned as useful items.

- While about one-third of audited households received special information on certified reliable insulation contractors, on lending institutions which provided conservation loans, and on tax credits which could be claimed for specific energy improvements, no household cited these items as useful aspects of the audit.

- More favorable assessment of the audit as a vehicle of new information on conservation options came from lowerincome, less educated households, those in units poorly weatherized, and those who previously indicated that there was little energy savings potential from additional weatherization.

- Interest in other aspects of utility assistance with conservation-aid in selecting a contractor, postinstallation inspections of contractor installed work, and interest free loans for conservation improvements-was expressed by fewer households than those favorably impressed with audits. Interest in these other forms of assistance is greater among audited than unaudited households, however. 
Section II provides a second and more rigorous basis of evaluating the effects of the audit. It compares the rates and types of activities reported by audited and unaudited households in the period intervening between the month of the audit and the follow-up survey.

- Considering all conservation actions, the audit had only a very small stimulating effect on the rate of new conservation effort.

- Audited households, in fact, made slightly fewer (not significant) higher cost efficiency improvements (e.g., attic insulation, storm windows) but (significantly) more lower cost improvements (caulking/weatherstripping) than unaudited households.

- Audited households also report more behavioral change to curtail energy use (e.g., use appliances less, lower temperature settings) but other indicators do not support this claim. Specifically, no large differences are evident in pre- and post-audit heating temperature settings of audited households nor between audited and unaudited households.

- Consistent with findings of previous research, households attribute the reason for most recent conservation actions to be the audit recoumendations, while it is likely that many of these actions would have been undertaken without the audit. This conclusion is based on the observation that the rate of conservation actions "not attributable" to the audit would be sharply lower among audited households than among unaudited units.

- Substantial shifts in the number and type of conservation actions from that planned at the time of the baseline survey is evident for both audited and unaudited samples. The greatest change for both groups was among households who could identify no needed improvements and who planned no improvements previously. At least 40 percent (depending on site and audit status) report some low or high-cost improvement in the intervening period, but the larger shifts from "no planned" to "some" activity do appear for audited households.

- While differences among audited and unaudited households are very modest, audits do appear to have stimulated lowcost actions among households with characteristics usually associated with lower rates of activity: renters, lower income groups, elderly homeowners, households in less well-insulated units. Audits also seemed 
to result in disproportionately more low-cost activity among households previously reporting that the major reason for not taking action was that they "were not sure of what to do" or that "further improvements were not needed" but had a less consistent effect on those who cited financial barriers to further investments.

Section III of this report evaluates the effect of the audit on household knowledge about appropriate conservation investments and choice of action characterized by the estimated payback.

- Fifteen to 25 percent of audited households can recall no energy-saving recommendations from the audit report they received.

- Households who cite specific recommendations of the audit are as likely to mention the longest payback (for their unit) item as they are the fastest payback item.

- Despite the fact that 90 percent of audited households had one or more options for energy efficiency improvements of five years or less, only about 50 percent made any such improvement.

- Thirty to 50 percent of all improvements had paybacks longer than ten years.

The concluding Section IV of this report briefly suggests possible reasons for the weak effect of audits in stimulating activity and reorienting investment choices.

The Appendix provides information on sample characteristics, possible biases in the samples, and the likely effects of bias on the principal conclusions of the study.

\section{Strengths and Limitations of The Study}

While several favorable impacts of audits have been identified, the summary conclusion of this study is that in-house audits in a format similar to those provided by utility companies under Residential Conservation Service regulations-do little to overcome barriers to 
economically optimum investment in residential energy efficiency. While this conclusion is more negative in tone than those reached by several other audit program evaluations, several strengths of the study design help to support this evaluation. This is one of few studies employing pre-audit and post-audit data collection on both audited and unaudited households. In addition, each study site was a concentrated geographic area so that wide variations in climate, local conservation ethic or culture, home construction practices, energy prices, and utility policies did not introduce confounding influences. Data on household's past activities over the entire period of tenure as well as general level of knowledge about remaining conservation opportunities and planned activities were collected prior to the audit so that comparisons with audit recommendations could be performed independently. We believe these strengths warrant strong credibility for the summary evaluation that audits do little to stimulate investment and overcome information barriers.

Despite these strengths, the sample selection and study design fell short of the ideal in several respects which should be kept in mind when assessing our findings, although we do not believe they invalidate our principal conclusions. 1

First, the sample of audited households does not represent the households typically audited by utility companies. Under nearly all current programs, households self-select for the audit by responding to

1. For suggestions about ideal study design for audit evaluations, also see Review of Evaluations of Utility Home Audit Programs, op. cit. Pp. 44-53. We compare limits of our study with the major recommendations contained in this reference. 
public or utility company notices. At a minimum, the household must initiate the audit by calling to schedule an appointment and, in most instances, pay the charge (of up to $\$ 15$ ) for the audit.

The typical audited household may be more predisposed to taking conservation actions than was our sample. However, this possibility would also make it difficult to judge audit impact in a sample of households seeking audits on their own. Because they are predisposed to action, the primary effect of the audit would be to alter the investment choice. If this is true, our study design may not be particularly inappropriate. A reasonable presumption would be that, even if unsolicited, the audit information would alter the choices of households who do make improvements. For households who did make investments, however, we detected little impact of the audit or investment choices. Second, even though only a small proportion of households in our study are likely to have initiated an audit without our assistance, the households were not randomly assigned to audit and non-audit status. Self-selection by signing a request form and by active participation in scheduling the audit was necessary. We observed a resulting bias toward slightly higher socioeconomic status and greater interest and plans for conservation among our audited samples. However, this should have had the effect of over-estimating rather than under-estimating audit effects on activity levels.

Third, we did not obtain independently verified information on actual energy consumption levels prior to and after audit, instead relying on self-reports of conservation actions. Its also well known that self-reported actions and behavior (e.g., temperature settings) may 
also be subject to bias toward perceived socially acceptable responses. We believe again, however, that this tendency should have produced greater over-reporting of action among audited households than among unaudited households. If true, this bias would not affect the basic conclusion of this study.

A fourth limitation in this study is the use of small sample sizes. While the intended sample in original study design was not large ( 150 at each site), the number of units audited was about 40 percent lower than planned. Consequently, the sample of audited households at each site ranges from 55 to 80 households (depending on the particular analysis). 1 Sample identification and size for the data is noted throughout the text and tables. Small sample sizes have made it difficult to identify statistically significant results and to perform extensive multivariate breakdowns. While larger samples would offer greater statistical validity, the observed differences in our study are small, suggesting that even statistically significant differences may not be large enough to warrant significance for the audit program.

\footnotetext{
1. The Appendix provides information for comparing the characteristics of the sample response rates, and sample sizes.
} 
I. HOUSEHOLD EVALUATION OF THE AUDIT

\section{General Assessment}

Households who received audits in this study offer strong but not universal approval of the audits they received. This assessment is based on a special supplement of questions in our follow-up survey which were addressed to audited households at the end of the interview. Several dimensions of this assessment are summarized for the audit sample at both sites and presented in Table $I-1$.

From 60 to 70 percent of households reported that the audit provided new information on ways to save energy of which they were previously unaware. About 85 percent thought the audit was accurate and over 90 percent thought it was worthwhile. Six to 20 percent of households reporting it was worthwhile (when free) said, however, they would not have paid $\$ 15$ (the usual charge) for the audit.

In analysis not shown, we attempted to identify households who would not pay for the audit as an indicator of the effects of audit price on the characteristics of participants. This issue has received attention by state utility commissions as they established utility audit program guidelines. 1 No systematic evidence supporting, for instance, lower income or elderly household unwillingness to pay the audit charge was found in our audit samples.

\footnotetext{
1. See, for example, testimony by Mitchell Rosenberg of the Technical Development Corporation before the Missouri Public Service Coumission, transcript, September 1980, for a review of issues on audit pricing.
} 
TABLE I-1

HOUSEHOLD EVALUATION OF THE HOME ENERGY AUDIT, D.C. AND DENVER

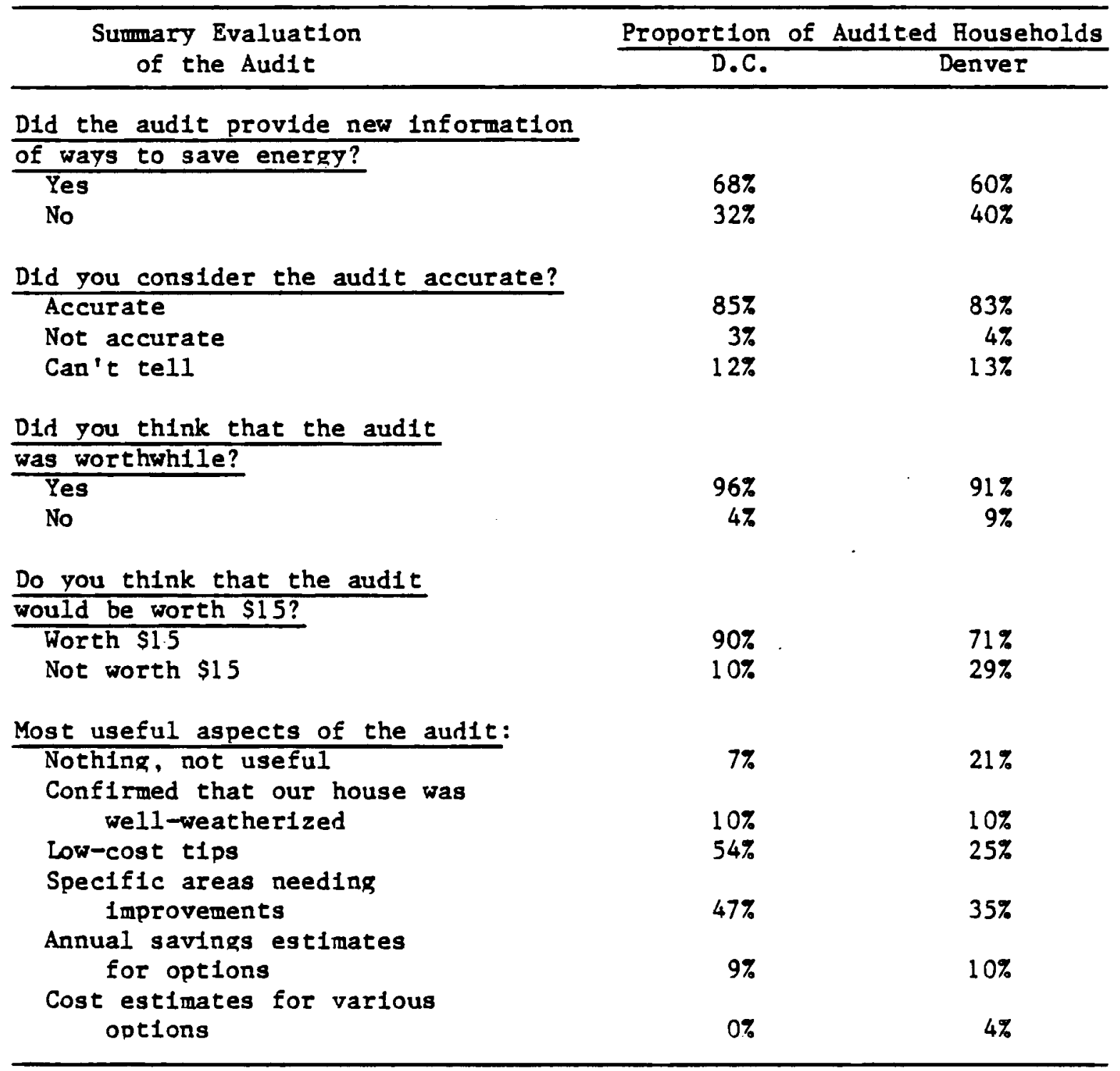

Sample Base: Audited Households in Follow- Ip Survey 
Table I-1 also shows aspects of the audit which were cited as most useful by audit respondents. Favored aspects were clearly "low-cost tips" (provided on-site by the auditor) and identification of major areas needing improvement. The detailed information in the audit report including estimates of contractor installed cost or cost of materialsinformation which would require substantial household "shopping" effort-was mentioned by less than 10 percent of respondents. Estimates of savings that could result from various improvement's to their unit given its current thermal status and the household's energy consumptionprobably the most unique information available from the audit-was not specifically mentioned by any D.C. households and by only 4 percent of Denver households.

Several items not shown in the table that we expected to be of use. to households who might be about to make major improvements were not mentioned by any of the audited households. 1 About 30 percent of audited households received lists of recomended (reliable) contractors for installation of insulation in their area (D.C.) and lists of lending institutions active in making home improvement loans to cover conservation retrofit. No respondents mentioned that this information was useful. This is significant because at least some state energy offices and public service commissions and utilities have devoted significant attention to the process by which contractors, for instance, should be

1. The response distribution in Table I-1 for "most useful aspects" is based on up to two openended responses. Only about 30 percent of households offered a second response, so we feel it unlikely that some of the unobserved responses were excluded by the question's wording asking for the most useful suggestions. 
included on such a list. ${ }^{1}$ Another one-third of households received an illustrative tax credit calculation for the recommended major items found by the audit for the individual household. This information also failed to be mentioned by any audited household.

While the household evaluation provided a favorable impression of the audit, it is noteworthy that there is a persistent difference over several measures in audit satisfaction between sites. A smaller proportion of Denver households offer favorable responses and 21 percent (versus 7 percent) of the Denver sample indicated that no aspects of the home audit were useful. Because there were numerous differences in the audits between sites in terms of scheduling, audit format, and (undoubtedly) auditor style and presentation, it is not possible to isolate any particular difference between audits that would account for site differences in satisfaction. Information (as opposed to format) provided by the audits was highly similar between sites.

It is also possible that differences between households at the two sites would account for lower satisfaction. ${ }^{2}$ One explanation would be that associated with climate. Because Denver households are better weatherized on average than are D.C. households, households may be more familiar with conservation items and practices. Consequently, the audit could offer less information previously unknown to the household.

1. This statement is based on the author's discussions with representatives of utilities involved with the study.

2. See discussion and comparison of utility audit procedures provided in Barriers to Energy Conservation..., op. cit., in Section III and Appendix; and The Conservation Gap Study: Purpose, Research Design and Data Collection, op. cit. 
While these factors cannot be assessed in this study, we are able to compare the distribution of favorable opinions among various types of households at each site. Information one measure of audit evaluationnew information provided-is shown by selected demographic and conservation characteristics in Table I-2. Both lower income and less educated households at both sites are more likely to report that the audit provided new information. The pattern for elderly households is inconsistent, however, between sites except that it is clear that "elderly only" households were less favorably impressed than all other households audited.

Households in units less wel1-weatherized (measured by fewer major features in place) and those who thought (previously) that little or no additional savings potential for their unit existed were more likely to have found the audit useful. Households differentiated by activity level (previous installation of major items) show no consistent pattern across sites.

While only some of the relationships presented in Table I-2 are statistically significant, the picture they suggest is that audits do find a favorable reception among targets appropriate for conservation improvements, specifically those of lower economic status, those whose units need improvement and whose beliefs about energy savings might well be altered.

Preference For Additional Utility Company Assistance

As part of the RCS, many utilities also offer aid to households in dealing with energy retrofit contractors. In addition, to overcome financial barriers to further investment, utilities in several areas 
TABLE I-2

CHARACTERISTICS OF HOUSEHOLDS WITH FAVORABLE EVALUATION OF THE AUDIT

Report that Aud1t Provided New Information for Making Weatherization Improvements

Proportion of Audited Households

Annual Income

Less than $\$ 15,000$

$\$ 15,000$ to 25,000

$82 \%^{*}$

$63 \%$

$\$ 25,000$ and over

$77 \%$

$58 \%$

$59 \%$

$55 \%$

Education ${ }^{a}$

Less than high school

$77 \%$

$60 \%$

Completed high school or higher

$60 \%$

$50 \%$

Elderly Status ${ }^{b}$

No elderly present

Some elderly present

$63 \%$

$83 \%$

$65 \%$

only elderly present

$64 \%$

$50 \%$

$50 \%$

Weatherization Status of Unit ${ }^{c}$

Less wel1-weatherized

$72 \%$

$68 \%$

We11-weatherized

$68 \%$.

$52 \%$

Previous Conservation Activity

Low

H1gh

$44 \%$

Savings Potential of Additional

Weatherization

Moderate tu high

$50 \%^{*}$

$57 \%$

Lttle or nothing

$80 \%$

$61 \%$

Sample Base: Audited Households in Follow-Up Survey

* Significant at .1.

a. Education is for most educated person in household.

b. Elderly is defined as adult aged 60 or over.

c. Weatherization status is based on presence of four items:

attic or wall insulation, storm windows, and doors.

d. Previous conservation activity is based on four mafor features

(Identified in $c$ above) elther added to or installed by current resident.

e. Savings potential of unit is based on response in baseline

survey to question concerning monthly savings that could be realized

from additional efficiency improvements. 
have offered or are considering offering financial assistance via interest-free or reduced cost loans for conservation improvements. These services were not offered as part of the current study. We assessed general interest in these aspects of utility assistance in our interview of audited households and results are presented in Table I-3. Twenty to 40 percent of all households indicated that they would definitely use assistance in selecting a contractor and 35 to 70 percent said they would definitely make use of utility post-installation inspection of contractor installed improvements. These responses, of course, are conditional upon the likelihood of the household undertaking some improvement for which these forms of assistance are appropriate. It is clear that post-installation inspection is more extensively preferred than assistances with initial selection. 1

Audited households are significantly more inclined to prefer utility assistance in these two contracting areas than are unaudited households. However, it is not known whether this difference is derived from the favorable experience with the audit or from a greater trust of utilities which led these households both to participate in the audit and to prefer additional assistance. The offer of an interest-free loan met with less receptivity than contractor assistance and has only slightly (and insignificant) greater acceptance among audited households. The loan was described as offering up to $\$ 1,500$ specifically to make conservation improvements and would be repaid without interest over a five-year period by the addition of about $\$ 25$ (for maximum loan) to

1. These options were not tied to any specific conditions such as picking a contractor from a list proposed by the utility or suggesting that contractors would be penalized for faulty work. 
TABLE I-3

PREFERENCES FOR UTILITY COMPANY ASSISTANCE IN

MAKING CONSERVATION TMPROVEMENTS

Other Forms of Utility

Company Assistance to

Households for Energy

Conservation Improvements
D.C.

\begin{tabular}{cccc} 
D.C. & \multicolumn{2}{c}{ Denver } \\
Houdited & $\begin{array}{c}\text { Other } \\
\text { Households }\end{array}$ & Audited & Other \\
Households & Households & Households
\end{tabular}

Prefer Utility Assistance

In Selecting a Contractor

Definitely

Maybe

No

Prefer Ut1lity Inspection of Contractor's Work

Defint
Maybe
No

Desire for $\$ 1500$

Interest-Free Loan from

Utility to Make Conser-

vation Improvements

Would take Ioan

Would not take loan

\section{$43 \%$}

$31 \%$

$26 \%$

$68 \%^{* \star}$

$19 \%$

$13 \%$

$60 \%$

$40 \%$
$34 \%$

$31 \%$

$35 \%$

$46 \%$

$26 \%$

$28 \%$
$33 \%$ *

$36 \%$

$32 \%$

$30 \%$

$49 \%$

Sample Base: All Households in Follow-Up Survey.

$\mathrm{N}=218$ and 209 respectively for D.C. and Denver. 
the monthly utility bill. Despite the obvious financial advantage of such a loan, about 50 percent of households were uninterested, exhibiting a reticence to borrow funds to finance improvements that has been found in other research. ${ }^{1}$ The most common reason cited for not wanting to take a loan was simply that it was not the household's practice to take loans. Much less frequently mentioned were the facts that the household could not afford such a loan or that no major conservation improvements were needed.

\section{Actions Attributed to The Audit}

Audited households attributed a wide variety of recent (since audit) actions to the audit. The distribution of improvements made and actions taken are shown in Table I-4. By far the most frequently mentioned was caulking and/or weatherstripping (29 percent and 22 percent respectively of all audited households in D.C. and Denver). Lower cost actions and behavioral changes (lowered temperature settings) were more frequently mentioned than were major improvements. Forty-two percent of D.C. households and 26 percent of Denver households mentioned at least one low-cost action in response to the audit.

Table I -4 also indicate that activity rates for nearly every item were lower in Denver. One likely reason for this was the difference between sites in the time that had elapsed since the audit. Audits in D.C. were completed by May, while in Denver they were completed in early September. Since follow-up interviewing was conducted in late January

1. See Technical Development Corporation testimony, op. cit., for similar results and Residential Energy Conservation by the Office of Technology Assessment; Vol. I (G.P.O. 非0-003-00691, Washington, D.C.), Chapter V. 
TABLE I-4

RECENT CONSERVATION ACTIONS ATTRIBUTED TO

THE AUDIT BY AUDITED HOUSEH OLDS ${ }^{a}$

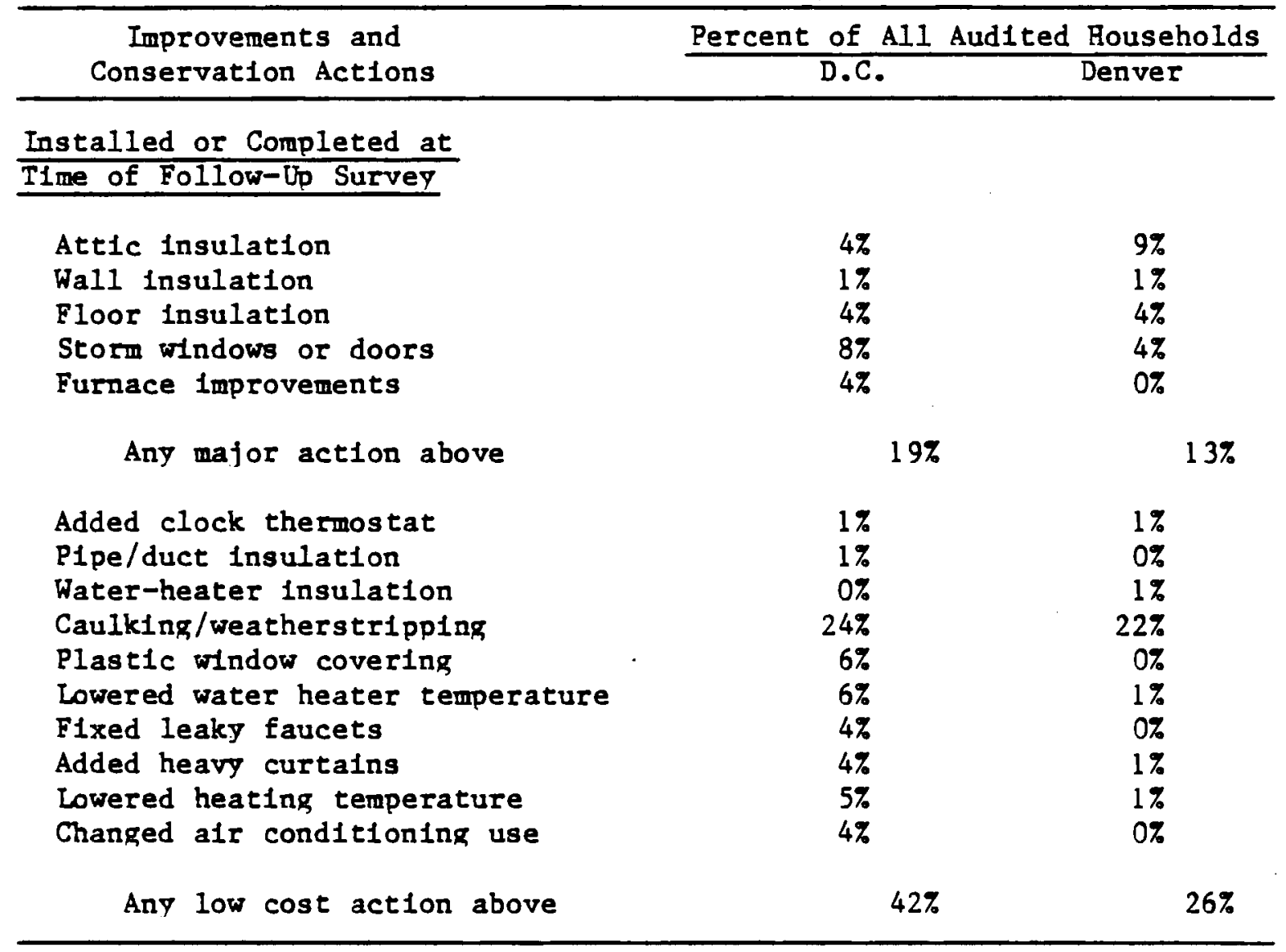

Sample Base: Aud1ted Households in Follow-Dp Survey

a. Actions reported here are based on multiple open-ended responses to questions for audited households asking what actions were prompted by the audit. (This is distinct from other measures of all actions reported by these households.) 
at both sites, this meant a period difference of three to four months between sites. While it is not likely that numerous conservation actions were conducted by D.C. residents during sumer months, the lateness of the Denver audits clearly offered less lead time for households to evaluate the audit, plan and undertake action.

However, the dominant reasons mentioned for not taking action do not support this speculation. As shown in Table I-5, only 3 percent of Denver households (versus 22 percent in D.C.) indicated that unsufficient time was a problem. Financial considerations of a temporary nature ("can't afford items at this time" due to unemployment, other major expenses, etc.) was the dominant concern of Denver households. This response seems to be borne out by the strong relationship between financial considerations and household income and assets (as shown at the bottom of Table $(-4)$. Financial considerations were less frequently cited by D.C. residents and bear less relationship to income. (In fact, those with greater assets in D.C. were more likely to cite financial constraints for not taking action than were those with fewer assets.)

\section{Summary of Household Evaluations}

Consistent with other reviews of audit programs, audited households hold favorable impressions of the audit they have received. They attribute numerous actions and improvement to the audit. However, at least one-quarter exhibit no interest in other contractor-related services that could be provided and nearly half are hesitant to take an interest-free loan. Yet financial barriers are most frequently cited by those who have taken no action since the audit. 
TABLE I-5

REASONS CITED FOR NOT TARING ACTIONS RECOMMENDED BY AUDIT

Responses to "What Are the Main Reasons You Haven't Taken Any Actions (yet) Based on the Aud1t?"

I plan to; not enough time

W11l never be able to afford reconmended items

Cannot afford items at this time (temporary)

I did not think suggestions were correct or worthwhile

Can't find contractor or materials

Too busy, too much trouble, will

disrupt my home

Physical infirmity, can't do

the work myself

Plan to move or don't own home

or other unclassifled
Proportion of Audfted Households Who Have Taken No Action ${ }^{a}$

D.C. Denver

$22 \%$

$3 \%$

$17 \%$

$14 \%$

$22 \%$

$42 \%$

$11 \%$

$6 \%$

$3 \%$

$3 \%$

$11 \%$

$8 \%$

$6 \%$

$3 \%$

$8 \%$

$36 \%$

"Affordability as a Reason by

Household Income and Assets"h

Annual income

Less than $\$ 15,000$

$\$ 15,000$ to 25,000

$\$ 25,000$ and over

$60 \%$

$45 \%$

$71 \%$

$41 \%$

$50 \%$

Major assets $c$

Less than $\$ 1,000$

$33 \%$

$33 \%$

Savings greater than $\$ 1,000$ or

other substantial assets

$53 \%$

$60 \%$

$50 \%$

Sample Base: Audited Households in Follow-Up Survey

a. Base of percentages are audited households who report no major or minor conservation actions in response to the audit: 41 percent in

D.C. and 49 percent in Denver.

b. Responses by income and assets are households saying they can-

not now or will never be able to afford conservation items because of

their cost (second and third reasons shown in top part of table).

c. Assets are classified as "high" if bank savings exceeding $\$ 1,000$ or savings bonds, stocks, rental property or business investments are reported. Assets are classified "low" if nefther savings in excess of $\$ 1,000$ nor other assets are reported. 
Despite these favorable impressions, it is important to note that a key aspect of the audit-its detailed cost, savings and payback calculations "are not the dominant useful elements of information" that audited households recall. Yet, the (usually) computer-assisted analysis and the detailed site measurements performed by the auditor represent substantial cost in a class $A$ audit. If low-cost tips and "identification of specific areas needing improvements" are indeed the most useful aspect of the audit, a more rapid and less costly walk-through site inspection with a specific discussion of weatherization features which could be improved-e.g., caulking and weatherstripping-might well result in equally satisfactory evaluation. Since low-cost and behavioral changes were also the most frequent actions attributed. to the audit, the walk-through audit may be equally as effective in stimulating household conservation effort. 


\section{EFFECTIVENESS OF THE AUDIT IN STIMULATING CONSERVATION ACTION}

Comparison of Reported Acts

This section provides a comparison of conservation activity levels among audited and unaudited households in the period after the audit. It employs the strengths of the quasi-experimental design to assess audit effectiveness. The test is whether or not conservation efforts among audited households is greater than that which might otherwise have occurred in response to the market force of rising energy prices and the normal sequential upgrading and improvement that households make to their dwelling units.

A wide range of possible high-cost and low-cost actions are assessed in both the audited and unaudited samples. Particular attention is paid to the low-cost options including caulking/weatherstripping, clock thermostats, and water heater insulation which offer high energy savings relative to cost and, which we knew from analysis of audit results, had been recommended for a large proportion of the audited households in our samples.

Table II-1 offers a detailed comparison of the proportion of households reporting various activities in both the audited and unaudited follow-up samples and the control samples. While many actions appear with greater frequency among audited households, only for caulking and 
TABLE II-1

COMPARISON OF CONSERVATION ACTIONS REPORTED BY AUDITED

AND UNAUDITED SAMPLES SINCE TIME OF THE AUDIT

\begin{tabular}{|c|c|c|c|c|c|c|}
\hline \multirow{3}{*}{$\begin{array}{l}\text { Conservation } \\
\text { Improvements } \\
\text { and Actions }\end{array}$} & \multicolumn{3}{|c|}{ D.C. } & \multicolumn{3}{|c|}{ Denver } \\
\hline & \multirow[b]{2}{*}{$\begin{array}{l}\text { Audited } \\
\text { Sample }\end{array}$} & \multicolumn{2}{|c|}{ Not Audited } & \multirow[b]{2}{*}{$\begin{array}{l}\text { Audited } \\
\text { Sample }\end{array}$} & \multicolumn{2}{|c|}{ Not Audited } \\
\hline & & $\begin{array}{l}\text { Follow-up } \\
\text { Sample }\end{array}$ & $\begin{array}{l}\text { Control } \\
\text { Sample }\end{array}$ & & $\begin{array}{l}\text { Follow-up } \\
\text { Sample }\end{array}$ & $\begin{array}{l}\text { Control } \\
\text { Sample }\end{array}$ \\
\hline$\frac{\text { Speciflc Improve- }}{\text { ments Reported }}$ & & & & & & \\
\hline Attic Insulation & $5 \%$ & $3 \%$ & $7 \%$ & $3 \%$ & $5 \%$ & $7 \%$ \\
\hline Wall insulation & $5 \%$ & $6 \%$ & $2 \%$ & $3 \%$ & $4 \%$ & $2 \%$ \\
\hline Floor Insulation & $4 \%$ & $4 \%$ & NA & $0 \%$ & $2 \%$ & NA \\
\hline Storm doors or windows & $8 \%$ & $12 \%$ & $47^{d}$ & $8 \%$ & $7 \%$ & $57^{\mathrm{d}}$ \\
\hline $\begin{array}{l}\text { Caulk1ng/weather- } \\
\text { strlpping }\end{array}$ & $54 \%$ & $52 \%$ & 597 & $40 \%^{*}$ & $27 \%$ & $48 \%$ \\
\hline $\begin{array}{l}\text { Water plpe/heating } \\
\text { duct insulation }\end{array}$ & $5 \%$ & $1 \%$ & NA & $0 \%$ & $2 \%$ & NA \\
\hline $\begin{array}{l}\text { Hot water heater } \\
\text { Insulation }\end{array}$ & $5 \%$ & $3 \%$ & $5 \%$ & $10 \%$ & $8 \%$ & $18 \%$ \\
\hline $\begin{array}{l}\text { Furnace/flue } \\
\text { Improvements }\end{array}$ & $9 \%$ & $4 \%$ & NA & $7 \%$ & $2 \%$ & NA \\
\hline $\begin{array}{l}\text { Clock thermostat } \\
\text { Plastic window }\end{array}$ & $4 \%$ & $3 \%$ & $\mathrm{NA}$ & $1 \%$ & $2 \%$ & NA \\
\hline covering & $24 \%$ & $29 \%$ & NA & $7 \%$ & $8 \%$ & NA \\
\hline $\begin{array}{l}\text { Heavy curtains for } \\
\text { window insulation }\end{array}$ & $4 \%$ & $1 \%$ & NA & $1 \%$ & $1 \%$ & NA \\
\hline
\end{tabular}


TABLE II-1 (continued)

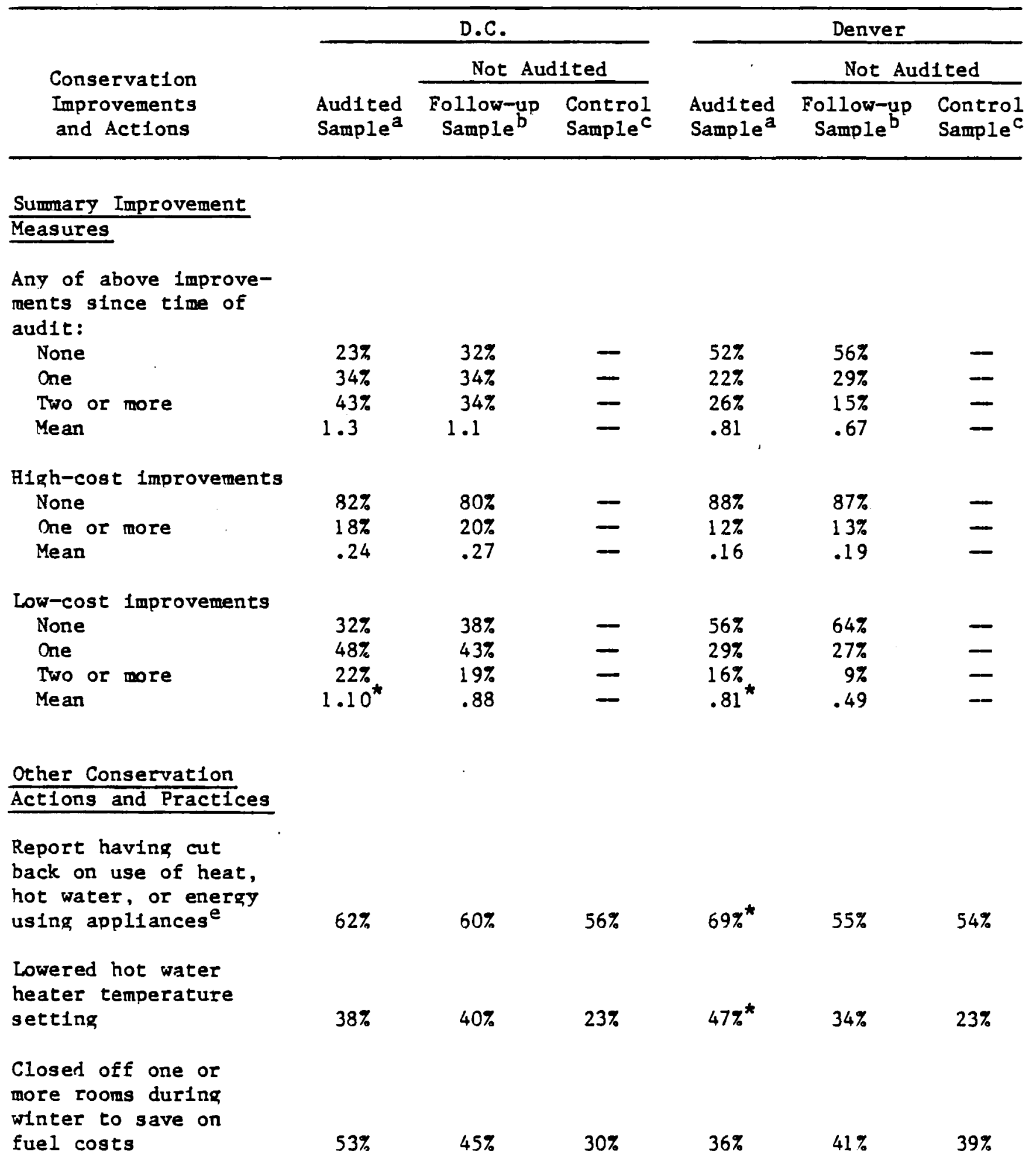


TABLE II-1 (continued)

\begin{tabular}{|c|c|c|c|c|c|c|}
\hline \multirow{3}{*}{$\begin{array}{l}\text { Conservation } \\
\text { Improvements } \\
\text { and Actions }\end{array}$} & \multicolumn{3}{|c|}{ D.C. } & \multicolumn{3}{|c|}{ Denver } \\
\hline & \multirow[b]{2}{*}{$\begin{array}{l}\text { Audited } \\
\text { Sample }\end{array}$} & \multicolumn{2}{|c|}{ Not Audited } & \multirow[b]{2}{*}{$\begin{array}{l}\text { Aud1 ted } \\
\text { Sample }\end{array}$} & \multicolumn{2}{|c|}{ Not Audited } \\
\hline & & $\begin{array}{l}\text { Follow-up } \\
\text { Sample }\end{array}$ & $\begin{array}{l}\text { Control } \\
\text { Sample }\end{array}$ & & $\begin{array}{l}\text { Follow-up } \\
\text { Sample }\end{array}$ & $\begin{array}{l}\text { Control } \\
\text { Sample }\end{array}$ \\
\hline $\begin{array}{l}\text { Pre-audit winter } \\
\text { daytime thermostat } \\
\text { setting (MEAN) }\end{array}$ & $69^{* \star}$ & 70 & NA & 68 & 69 & NA \\
\hline $\begin{array}{l}\text { Post-audit winter } \\
\text { daytlme thermostat } \\
\text { setting (MEAN) }\end{array}$ & $69^{\star}$ & 70 & 70 & 66 & 67 & 67 \\
\hline $\begin{array}{l}\text { Pre-audit winter } \\
\text { nighttime thermostat } \\
\text { setting (MEAN) }\end{array}$ & 67 & 67 & NA & 65 & 64 & $\mathrm{NA}$ \\
\hline $\begin{array}{l}\text { Post-aud1t winter } \\
\text { nighttime thermostat } \\
\text { setting (MEAN) }\end{array}$ & 66 & 67 & 68 & 65 & 64 & 65 \\
\hline
\end{tabular}

Sample Base: Aud1ted and Unaudited Households in Follow-up Sample and Post-Aud1t Control Samples

* Significant at .1.

** Significant difference at .05 level between audited and unaudited households in follow-up survey.

NA Not avallable on comparable basis in post-control sample.

a. Audited sample who were re-contacted in follow-up survey. $N=79$ in

D.C. and 77 in Denver.

b. Unaudited sample were households in baseline survey who were recontacted in follow-up survey. $N=139$ in D.C. and 132 in Denver.

c. Post-control sample were first contacted during follow-up interview period. $N=100$ each in D.C. and Denver. audit.

d. For control samples, percent includes only storm windows since month of

e. For control sample, includes any cutbacks ever reported (even if done prior to month of audit at that site). For follow-up samples, includes only actions clted as performed since month of audit. 
weatherstripping are proportions different enough to warrant statistical significance at the .1 level and only for Denver. 1

Because conservation efforts are dispersed over so many different activities, we have provided summary measures in the middle portion of the table. Audited households at both sides report a greater number of actions overall. Mean differences are small, however-an average of two-tenths of an action-in both sites.

Our summary for high-cost improvements (top five items on list) indicates that these actions were actually taken less frequently by audited than unaudited households. Low-cost improvements account for the difference and show the only consistent statistically significant effect of the audit with respect. to energy efficiency improvements. The bottom portion of the table compares other reported actions to curtail energy use. Audited households in Denver report at least one action to curtail use with more frequency than unaudited households (69 versus 55 percent). The Denver audit sample also reports having lowered water-heater temperature settings-a specific audit recommendation--with significantly greater frequency than unaudited households. These differences, however, are not evident in D.C.

As another behavioral measure we compared (self-reported) daytime and nighttime temperature settings which typically represent the most

\footnotetext{
1. The control sample activities bear no consistent relationship in comparison to audit and follow-up samples. The original purpose of collecting control sample data was to identify the possible effects of our initial baseline interview itself on household conservation interest and actions. Unfortunately, the control samples picked up an usually high number of older headed households, a characteristic associated with lower conservation activity. See Appendix for discussion of control sample bias and its limited use for comparison purposes.
} 
difficult behavioral adjustment to conserve on heating fuel consumption. The only mean difference that is significant at .05 is actually the pre-audit daytime temperature setting with pre-audit daytime setting of D.C. households. Pre- and post-audit survey daytime settings differ by two degrees for both audited and unaudited households in Denver. Average audited household temperature settings for nighttime actually exceed those of unaudited households in the follow-up sample. Overall, there are no important differences in temperature settings of audited and unaudited households.

Using this most direct and simple test of audit impact on conservation effort, we can attribute no major stimulative effects to energy audits. There is evidence for a reorientation of action, in the aggregate, away from higher cost improvements and toward lower cost actions but this effect-appears so small that it is of little significance in supporting a favorable evaluation of program impact. In addition, a shift from high-cost to low-cost actions may actually be a perverse outcome from the perspective of public policy. While such shifts may increase individual household efficiency (on the assumption that lowcost actions typically offer faster paybacks), they may deter or dampen the conservation of scarce energy resources from that which might have (less efficiently) occurred if households had not been audited.

\section{Possible Explanation For Divergence of Findings}

Because these findings suggest that audits are less effective than implied by analysis in Section I and by some previous research, it is used to compare the distribution of actions separated into two components. We have calculated the difference between reported actions of 
audited households and actions specifically attributed by them to the audit. We compare the resulting activity rates to rates among unaudited households. ${ }^{1}$ Results are presented in Table II-2.

A substantial portion of actions reported by audited households have been attributed to the audit. If all data were accurately measured, we could anticipate that households reporting these actions (col. 1, both sides of table) would represent the "true" incremental effect of the audit. We would correspondingly expect the percentages of remaining households reporting these actions to fall close to the proportions reporting actions in the audited sample. This is clearly not the result for most actions. (The exceptions are hot water heater insulation and furnace/flue opening alternative--two low-cost actions frequently recommended for our audited households and which we would have expected to be more frequently attributed to the audit.) For example, the most frequent improvement-caulking/weatherstripping-would have been performed by 10 to 20 percent fewer audited households than unaudited householdss.

The important implication of this result is that audited households apparently attribute to the audit many conservation actions and efficiency improvements they are likely to have made without the audit.

1. These activity rates were measured with separate questions in the survey. Our initial questions of all households dealt with recent conservation actions since the (month) of audit. Our supplemental questions (of audited households) dealt with specific action attributes taken because of the audit. 
TABLE II-2

COMPARISON OF CONSERVATION ACTIONS TAKEN SINCE THE AUDIT AND ACTIONS ATTRIBUTED TO THE AUDIT

\begin{tabular}{|c|c|c|c|c|c|c|}
\hline \multirow[b]{2}{*}{$\begin{array}{c}\text { Selected } \\
\text { Conservation } \\
\text { Improvements }\end{array}$} & \multicolumn{3}{|c|}{ D.C. } & \multicolumn{3}{|c|}{ Denver } \\
\hline & $\begin{array}{l}\text { Attributed } \\
\text { to Audit }\end{array}$ & $\begin{array}{l}\text { Not } \\
\text { Attributed } \\
\text { to Audit } \\
(\text { Net })^{b}\end{array}$ & $\begin{array}{l}\text { Unaudited } \\
\text { Sample }\end{array}$ & $\begin{array}{l}\text { Attributed } \\
\text { to Audit }\end{array}$ & $\begin{array}{l}\text { Not } \\
\text { Attributed } \\
\text { to Audit } \\
(\text { Net })^{b}\end{array}$ & $\begin{array}{l}\text { Unaudited } \\
\text { Sample }\end{array}$ \\
\hline $\begin{array}{l}\text { Attic } \\
\text { insulation }\end{array}$ & $4 \%$ & $1 \%$ & 37 & $3 \%$ & $0 \%$ & $5 \%$ \\
\hline $\begin{array}{l}\text { Wall } \\
\text { Insulation }\end{array}$ & $1 \%$ & $4 \%$ & $6 \%$ & $1 \%$ & $2 \%$ & $4 \%$ \\
\hline $\begin{array}{l}\text { Floor } \\
\text { insulation }\end{array}$ & $4 \pi$ & $0 \%$ & $4 \%$ & $0 \%$ & $0 \%$ & $2 \%$ \\
\hline $\begin{array}{l}\text { Storm } \\
\text { windowg/doors }\end{array}$ & $8 \%$ & $4 \%$ & $12 \%^{\circ}$ & $4 \%$ & $4 \%$ & $7 \%$ \\
\hline $\begin{array}{l}\text { Caulking/ } \\
\text { weatherstripping }\end{array}$ & $24 \%$ & $30 \%$ & $52 \%$ & $22 \%$ & $18 \%$ & $27 \%$ \\
\hline $\begin{array}{l}\text { P1pe/duct } \\
\text { insulation }\end{array}$ & $1 \%$ & $4 \%$ & $1 \%$ & $0 \%$ & $0 \%$ & $2 \%$ \\
\hline $\begin{array}{l}\text { Hot water heater } \\
\text { insulation }\end{array}$ & $0 \%$ & $5 \%$ & $3 \%$ & $1 \%$ & $9 \%$ & 87 \\
\hline $\begin{array}{l}\text { Furnace/flue } \\
\text { improvements }\end{array}$ & $4 \%$ & $5 \%$ & $4 \%$ & $0 \%$ & $7 \%$ & $2 \%$ \\
\hline $\begin{array}{l}\text { Clock } \\
\text { thermostat }\end{array}$ & $1 \%$ & $3 \%$ & $3 \%$ & $1 \%$ & $0 \%$ & $2 \%$ \\
\hline $\begin{array}{l}\text { Plastic window } \\
\text { covering }\end{array}$ & $6 \%$ & $18 \%$ & $24 \%$ & $0 \%$ & $7 \%$ & $8 \%$ \\
\hline Heavy curtains & $4 \%$ & $0 \%$ & $1 \%$ & $1 \%$ & $0 \%$ & $1 \%$ \\
\hline
\end{tabular}

Sample Base: Audited and Unaudited Households in Follow-Up Survey a. These percentages are based on audited households' responses to spectflc questions on actions taken because of the audit recommendations (see Table I-2). b. These percentages are calculated for audited households by subtracting from percentage reporting actions since time of audit (June in D.C.; August in Denver), the percentage (in colum 1) attributing action to audit.

c. Percentages are based on actions since month of audit by unaudited households in follow-up survey. (Same as reported in Table II-1 for this group.) 
Audit Effects and Previously Planned Activities

The apparent shift of activity away from higher cost actions that was observed in the aggregate among audited households can be assessed using other data available in the study. We are able to compare preaudit planned actions and conservation information with action reported after the audit. Because shifts from planned activity may have also occurred with some frequency in unaudited households, it will be appropriate to relatively assess these shifts among households in both the audited and unaudited follow-up samples.

Table II-3 first shows the pre-audit differences with respect to "needed improvements" and planned activities. In both D.C. and Denver, a greater proportion of households who were audited could identify one or more efficiency improvements they thought were needed in their unit. By about nine percentage points in each site, audited households were also more likely to say that one or more specific improvements were definitely planned (prior to next winter) at the time of our baseline interview.

By the time of the reinterview, significant proportions of both audited and unaudited households who could either not identify needed improvements or had no specific plans had made one or more improvements: Audited households, however, clearly show the greater proportionate increase, and the largest impact was for those who previously could identify no needed improvement. In D.C., 80 percent of the audited households reported some action compared to 65 percent of unaudited households. In Denver, 71 percent of audited households 
TABLE II-3

CONSERVATION ACTIONS UNDERTAKEN SINCE THE ALDTT AND PREVIOUSLY IDENTIFIED IMPROVEMENTS AND PLANS ${ }^{a}$

\begin{tabular}{|c|c|c|c|c|}
\hline \multirow{2}{*}{$\begin{array}{l}\text { Household Character- } \\
\text { Istics with Respect } \\
\text { to Post-Audit Actions } \\
\text { and Pre-Audit } \\
\text { Knowledge and Plans }\end{array}$} & \multicolumn{2}{|c|}{ D.C. } & \multicolumn{2}{|c|}{ Denver } \\
\hline & $\begin{array}{l}\text { Unaudited } \\
\text { Households }\end{array}$ & $\begin{array}{c}\text { Audited } \\
\text { Households }\end{array}$ & $\begin{array}{l}\text { Onaudited } \\
\text { Households }\end{array}$ & $\begin{array}{c}\text { Audited } \\
\text { Households }\end{array}$ \\
\hline
\end{tabular}

Proportion 1dentifying

some needed Improve-

ments prior to audit

$65 \%$

$75 \%$

$69 \%$

$82 \%$

Proportion who planned some Improvement prior to audit

Proportion of households reporting any activity out of all households who could identify no needed 1mprovement prior to audit $65 \%$ $84 \%$ $42 \%$ $71 \%$

Proportion of households reporting any activity out of all households who had no plans for improve-

Proportion of households reporting any major ${ }^{b}$ investment who had not planned major activity prior to audtt

Proportion of households reporting any low-cost ${ }^{c}$ improvement who had not planned any low-cost activity prior to audit 
TABLE II-3 (continued)

\begin{tabular}{|c|c|c|c|c|}
\hline \multirow{2}{*}{$\begin{array}{l}\text { Household Character- } \\
\text { 1st1cs with Respect } \\
\text { to Post-Aud1t Actions } \\
\text { and Pre-Aud1t } \\
\text { Knowledge and Plans }\end{array}$} & \multicolumn{2}{|c|}{ D.C. } & \multicolumn{2}{|c|}{ Denver } \\
\hline & $\begin{array}{l}\text { Unaudited } \\
\text { Households }\end{array}$ & $\begin{array}{l}\text { Audited } \\
\text { Households }\end{array}$ & $\begin{array}{l}\text { Unaudited } \\
\text { Households }\end{array}$ & $\begin{array}{c}\text { Audited } \\
\text { Households }\end{array}$ \\
\hline $\begin{array}{l}\text { Of those households } \\
\text { planning no activity } \\
\text { prior to audit: }\end{array}$ & & & & \\
\hline $\begin{array}{l}\text { Report one or more } \\
\text { major 1mprovements }\end{array}$ & $18 \%$ & $20 \%$ & $8 \%$ & $15 \%$ \\
\hline $\begin{array}{l}\text { Report one or more } \\
\text { low-cost Improvements }\end{array}$ & $64 \%$ & $67 \%$ & $32 \%$ & $51 \%$ \\
\hline $\begin{array}{l}\text { Of those households } \\
\text { planning some mator } \\
\text { activity prior to audit: }\end{array}$ & & & & \\
\hline Report no activity & $24 \%$ & $24 \%$ & $43 \%$ & $53 \%$ \\
\hline $\begin{array}{l}\text { Report one or more } \\
\text { major 1mprovements }\end{array}$ & $28 \%$ & $24 \%$ & $35 \%$ & $16 \%$ \\
\hline $\begin{array}{l}\text { Report one or more } \\
\text { low-cost 1mprovements }\end{array}$ & $58 \%$ & $71 \%$ & $48 \%$ & $47 \%$ \\
\hline $\begin{array}{l}\text { Of those households } \\
\text { planning some low-cost } \\
\text { activity prior to audit: }\end{array}$ & & & & \\
\hline Report no activity & $42 \%$ & $20 \%$ & $45 \%$ & $60 \%$ \\
\hline $\begin{array}{l}\text { Report one or more } \\
\text { major activities }\end{array}$ & $17 \%$ & $27 \%$ & $16 \%$ & $12 \%$ \\
\hline $\begin{array}{l}\text { Report one or more } \\
\text { low-cost activities }\end{array}$ & $42 \%$ & $73 \%$ & $52 \%$ & $40 \%$ \\
\hline
\end{tabular}

Sample Base: All Households in Follow-Up Sample

a. "Actions since the Aud1t" refers to major and low-cost conservation Improvements reported by both audfted and unaudted households in the followup survey. Actions were 1dentified with respect to time perlod-since June for D.C. and since August for Denver-the month after which audits were conducted in each site respectively.

b. Mafor Improvements have been identified without respect to actual expenditure, following conventional classification and include: attic, wall, and floor insulation, storm windows and doors, solar systems.

c. Low-cost Improvements include: caulking/weatherstripping, insulation of hot water pipes, heating ducts, or hot water heater; installation of plastic window coverings, heavy curtains, or clock thermostat; and furnace improvements such as new ignition systems or flue-opening modifications. 
identifying no needed improvements-compared to 42 percent of unaudited households-reported same efficiency improvement to their unit.

A further disaggregation to identify shifts from previous plans by type of activity is provided in the third part of Table II-3. of those households planning no previous activity, most completed a low-cost action (32 to 67 percent). In both sites audited households with no previous plans, were more likely to report both major and low-cost improvements than unaudited households although this difference is much greater in Denver than in D.C.

We can also examine shifts among previously planned major and minor actions, but results tend to be inconsistent by site. It is important to note that many households who said that they planned action report none at time of reinterview. Of those who planned major improvements, 29 percent in D.C. and 43 to 53 percent in Denver report none. of these groups, over 50 percent in each site report low-cost actions, while 16 to 35 percent reported a major activity (not necesssarily the specific ones planned). Of those planning low-cost activity, a greater proportion typically "shift" to no activity than did households planning major improvements. The largest proportion, 40 to 75 percent, carried through with some low-cost activity, however.

A summary of audit effects relative to previous plans would suggest the following picture. Audits stimulated relatively greater rates of activity for both high- and low-cost actions among those who previously had no activity planned. Among households with plans for major improvements the effects were mixed-stimulating activity in D.C. but dampening 
it in Denver. In D.C., households substituted low-cost improvements; in Denver, there was substitution of no activity.

On balance, the (slight) observed audit effect on action (from Table I-1) may be due to combination of offsetting influences: those without plans respond to the audit contributing most to the aggregate increase in activity. Many of those with plans for activity shift toward low-cost or no activity but not in proportions great enough to offset the increase from those without previous plans.

\section{Who Responds to Audits}

Since the most noticeable effect of the audit is an increase of low-cost activity, we have examined the relative rate among various groups for audited and unaudited households with respect to average lowcost actions reported. Results of these analysis are shown in Table II4. We first show homeowner/renter differences; the remainder of the table includes homeowners only.

Consistent with the results of the household evaluation (Section I) audits do tend to stimulate (more) favorable response among those households with characteristics usually associated with low conservation effort. Of audited households, those with lower income, less education (in Denver), the elderly, longer term residents, those in less weatherized units report, on average, more low-cost actions than unaudited households with the same characteristics. In addition, the mean difference for those groups-between audit and non-audit statustends to be as large, or greater than the mean difference observed for between other audited and unaudited groups. This funding, however, does not hold for those previously active in installing major features, 
TABLE II-4

LOW-COST CONSERVATION IMPRONEMENTS SINCE TIME OF AUDIT BY HOUSEHOLD CHARACTERISTICS ${ }^{2}$

\begin{tabular}{|c|c|c|c|c|}
\hline \multirow[b]{3}{*}{$\begin{array}{c}\text { Household } \\
\text { Characteristics }\end{array}$} & \multicolumn{4}{|c|}{ Mean Low-Cost Improvements } \\
\hline & \multicolumn{2}{|c|}{ D.C. } & \multicolumn{2}{|c|}{ Denver } \\
\hline & $\begin{array}{c}\text { Audited } \\
\text { Households }\end{array}$ & $\begin{array}{l}\text { Unaudited } \\
\text { Households }\end{array}$ & $\begin{array}{c}\text { Audited } \\
\text { Households }\end{array}$ & $\begin{array}{l}\text { Unaud1ted } \\
\text { Households }\end{array}$ \\
\hline$\frac{\text { Socloeconomic }}{\text { Characteristics }}$ & & & & \\
\hline Tenure: & & & & \\
\hline $\begin{array}{l}\text { Owners } \\
\text { Renters }\end{array}$ & $\begin{array}{l}1.0 \\
1.3\end{array}$ & $\begin{array}{l}.9 \\
.8\end{array}$ & $\begin{array}{l}.7 \\
.5\end{array}$ & $\begin{array}{l}.5 \\
.5\end{array}$ \\
\hline Income: & & & & \\
\hline $\begin{array}{l}\text { Less than } \$ 15,000 \\
\$ 15,000-\$ 25,000 \\
\$ 25,000 \text { and over }\end{array}$ & $\begin{array}{r}.9 \\
1.1 \\
.9\end{array}$ & $\begin{array}{r}.6 \\
1.0 \\
.9\end{array}$ & $\begin{array}{l}.7 \\
.6 \\
.6\end{array}$ & $\begin{array}{l}.5 \\
.4 \\
.5\end{array}$ \\
\hline $\begin{array}{l}\text { Education: } \\
\text { High school of less } \\
\text { More than high school }\end{array}$ & $\begin{array}{l}.9 \\
.9\end{array}$ & $\begin{array}{l}.9 \\
.9\end{array}$ & $\begin{array}{l}.7 \\
.6\end{array}$ & $\begin{array}{l}.4 \\
.5\end{array}$ \\
\hline $\begin{array}{l}\text { Elderly status: } \\
\text { No elderly adults } \\
\text { Some elderly adults } \\
\text { Only elderly adults }\end{array}$ & $\begin{array}{r}1.0 \\
1.1 \\
.5\end{array}$ & $\begin{array}{r}1.0 \\
.9 \\
.4\end{array}$ & $\begin{array}{l}.6 \\
.7 \\
.8\end{array}$ & $\begin{array}{l}.4 \\
.4 \\
.6\end{array}$ \\
\hline $\begin{array}{l}\text { Length of residence: } \\
1 \text { to } 6 \text { years } \\
6 \text { to } 20 \text { years } \\
20 \text { plus years }\end{array}$ & $\begin{array}{r}1.1 \\
.9 \\
.9\end{array}$ & $\begin{array}{r}1.1 \\
.8 \\
.8\end{array}$ & $\begin{array}{l}.6 \\
.7 \\
.6\end{array}$ & $\begin{array}{l}.7 \\
.3 \\
.5\end{array}$ \\
\hline $\begin{array}{l}\text { Pre-Aud1t Conservation } \\
\text { Status and Activities }\end{array}$ & & & . & \\
\hline $\begin{array}{l}\text { Less well-weatherized } c \\
\text { Wel1-weatherfzed }\end{array}$ & $\begin{array}{r}1.0 \\
.9\end{array}$ & $\begin{array}{l}.8 \\
.9\end{array}$ & $\begin{array}{l}.6 \\
.6\end{array}$ & $\begin{array}{l}.5 \\
.4\end{array}$ \\
\hline $\begin{array}{l}\text { Low activity leveld } \\
\text { High activity level }\end{array}$ & .8 & $\begin{array}{l}.8 \\
.9\end{array}$ & $\begin{array}{l}.6 \\
.7\end{array}$ & $\begin{array}{l}.5 \\
.4\end{array}$ \\
\hline $\begin{array}{l}\text { No recent activity } \\
\text { Recent major activity }\end{array}$ & $\begin{array}{r}.8 \\
1.3\end{array}$ & $\begin{array}{l}.9 \\
.6\end{array}$ & $\begin{array}{l}.6 \\
.7\end{array}$ & $\begin{array}{l}.4 \\
.5\end{array}$ \\
\hline
\end{tabular}


TABLE II-4 (continued)

\begin{tabular}{|c|c|c|c|c|}
\hline \multirow[b]{3}{*}{$\begin{array}{c}\text { Household } \\
\text { Charactertstics }\end{array}$} & \multicolumn{4}{|c|}{ Mean Low-Cost Improvements } \\
\hline & \multicolumn{2}{|c|}{ D.C. } & \multicolumn{2}{|c|}{ Denver } \\
\hline & $\begin{array}{l}\text { Audited } \\
\text { Households }\end{array}$ & $\begin{array}{l}\text { Unaud 1ted } \\
\text { Households }\end{array}$ & $\begin{array}{l}\text { Audited } \\
\text { Households }\end{array}$ & $\begin{array}{l}\text { Unaudited } \\
\text { Households }\end{array}$ \\
\hline $\begin{array}{l}\text { Could Identify no } \\
\text { needed improvements } \\
\text { Identifled one or more }\end{array}$ & $\begin{array}{r}1.1 \\
.9\end{array}$ & $\begin{array}{l}.7 \\
.9\end{array}$ & $\begin{array}{l}.9 \\
.6\end{array}$ & $\begin{array}{l}.3 \\
.5\end{array}$ \\
\hline \multicolumn{5}{|l|}{$\begin{array}{l}\text { Major Reason for not } \\
\text { Taking Additional Actions }\end{array}$} \\
\hline $\begin{array}{l}\text { "Not needed" is mentioned } \\
\text { Reason not mentioned }\end{array}$ & $\begin{array}{r}1.1 \\
.9\end{array}$ & $\begin{array}{l}.7 \\
.9\end{array}$ & $\begin{array}{l}.6 \\
.6\end{array}$ & $\begin{array}{l}.4 \\
.5\end{array}$ \\
\hline $\begin{array}{l}\text { "Not sure what to do" } \\
\text { Reason not mentioned }\end{array}$ & $\begin{array}{l}.9 \\
.9\end{array}$ & $\begin{array}{l}.7 \\
.9\end{array}$ & $\begin{array}{r}1.0 \\
.5\end{array}$ & $\begin{array}{l}.5 \\
.4\end{array}$ \\
\hline $\begin{array}{l}\text { "Can't afford" is } \\
\text { mentioned } \\
\text { Reason not mentioned }\end{array}$ & $\begin{array}{r}1.0 \\
.8\end{array}$ & $\begin{array}{r}1.0 \\
.6\end{array}$ & $\begin{array}{l}.7 \\
.6\end{array}$ & $\begin{array}{l}.4 \\
.5\end{array}$ \\
\hline
\end{tabular}

Sample Base: Households in Follow-Up Sample

a. With the exception of the first breakdown of means for tenure, all figures in the table are for homeowners only. Low-cost items are as defined in previous tables.

b. Education is for most educated person in household.

c. Weatherization status is based on presence of major features:

attic and wall insulation, storm windows and doors.

d. Activity level is for mafor features (in c. above) Installed by current resident over entire perfod of tenure.

e. Recent activity is for any major features (see c. above) installed since 1979 but prior to audit.

f. "Needed improvements" are any energy efficiency items respondent mentioned as appropriate for untt during baseline survey.

g. Mafor reasons are three most frequent response categorles to openended question in baseline survey on reasons for not making additional efficlency improvements. Reason was elther "mentioned" or "not mentioned." More than one reason could be mentioned by each respondent. 
either over course of tenure or recently. (For this measure, features include attic and wall insulation, storm windows and doors and recently is defined since 1979.) Households more active in the past responded strongly with low-cost measures when audited.

The audit seems to have helped as well in overcoming at least two of the three major barriers to actions. The bottom portion of the table indicates a larger increase in activity among households who were "unsure of what to do" or who believed that "no improvements were needed." The audit seemed to have less effect-even on low-cost actions-for those who cited financial reasons for not making additional efficiency improvements. 
III. EFFECT OF AUDITS ON HOUSEHOLDS CONSERVATION KNOWLEDGE AND CHOICE OF RETROFIT INVESTMENT

Changes in Household Awareness of Attractive Options

This section identifies the effects of the audit using a less

stringent test. We examine the level and change in audited households' knowledge about appropriate investment for their units, whether or not they have completed any major efficiency improvements at time of reinterview. Also, using information on efficiency improvements that are reported, we examine the economic attractiveness (based on audit payback) of improvements completed since the audit. This analysis addresses a second important aspect of audit programs--whether or not they successfully impart to households information on the most effective options.

Table III-1 provides a simple frequency distribution of responses to suggestions recalled by audited households from the audit report they received. Fourteen percent of D.C. households and twenty-three percent of Denver households could recall no improvements that would save them money from the audit (over 90 percent of households had one or more five-year payback options, however, according to the audit). of those whose were able to recall any, caulking/weatherstripping, storm door or windows, and attic insulation were the most frequent mentions. Insulation of walls, floors and hot water heaters were the next most frequently recalled items.

Table III-2 provides a detailed comparison of each household's responses with the recommendations for the unit from the audit, and it provides a pre- and post-audit comparison as well. The pre-audit 
TABLE III-1

HOUSEHOLDS' RECALL OF AUDIT RECOMENDATIONS

FOR ENERGY-SAVING IMPROVEMENTS

\begin{tabular}{|c|c|c|}
\hline \multirow{2}{*}{$\begin{array}{l}\text { Response to: "If you recall, what } \\
\text { were the mator suggestions made in } \\
\text { the (audit) report for 1mprovements } \\
\text { that would save you the most money?" }\end{array}$} & \multicolumn{2}{|c|}{ Proportion of Audited Households } \\
\hline & D.C. & Denver \\
\hline Cannot Recall Any & $14 \%$ & $23 \%$ \\
\hline Of Items Recalled & & - \\
\hline Improve caulking/weatherstripping & $40 \%$ & $49 \%$ \\
\hline Add storm windows/doors & $35 \%$ & $24 \%$ \\
\hline Insulate attic & $27 \%$ & $34 \%$ \\
\hline Insulate walls & $16 \%$ & $17 \%$ \\
\hline Insulate hot water heater & $16 \%$ & $14 \%$ \\
\hline Insulate floors & $16 \%$ & $5 \%$ \\
\hline Install clock thermostat & $9 \%$ & $3 \%$ \\
\hline Furnace 1mprovements & $9 \%$ & $2 \%$ \\
\hline Solar devices & $4 \%$ & $7 \%$ \\
\hline Insulate plpes/heating ducts & $4 \%$ & $2 \%$ \\
\hline Other & $28 \%$ & $14 \%$ \\
\hline
\end{tabular}


TABLE III-2

HOUSEH OOLDS PERCEPTIONS OF NEEDED ENERGY-SAVING

IMPROVEMENTS BEFORE AND AFTER THE AUDIT

\begin{tabular}{|c|c|c|c|c|c|c|c|c|}
\hline \multirow{3}{*}{$\begin{array}{l}\text { Efficiency } \\
\text { Improvements } \\
\text { Evaluated } \\
\text { by the } \\
\text { Audit }\end{array}$} & \multicolumn{4}{|c|}{ D.C. } & \multicolumn{4}{|c|}{ Denver } \\
\hline & \multicolumn{2}{|c|}{$\begin{array}{l}\text { Pre-Audit } \\
\text { Proportion } \\
\text { Identifying } \\
\text { Items with } \\
\text { Paybacks of } \\
\end{array}$} & \multicolumn{2}{|c|}{$\begin{array}{l}\text { Post-Audit } \\
\text { Proportion } \\
\text { Identifying } \\
\text { Items with } \\
\text { Paybacks of }\end{array}$} & \multicolumn{2}{|c|}{$\begin{array}{l}\text { Pre-Audit } \\
\text { Proportion } \\
\text { Identifying } \\
\text { Items wi th } \\
\text { Paybacks of }\end{array}$} & \multicolumn{2}{|c|}{$\begin{array}{l}\text { Post-Aud1t } \\
\text { Proportion } \\
\text { Identifying } \\
\text { Items with } \\
\text { Paybacks of } \\
\end{array}$} \\
\hline & $\begin{array}{l}5 \text { Years } \\
\text { or Less }\end{array}$ & $\begin{array}{l}10 \text { Years } \\
\text { or More }\end{array}$ & $\begin{array}{l}5 \text { Years } \\
\text { or-Less }\end{array}$ & $\begin{array}{l}10 \text { Years } \\
\text { or More }\end{array}$ & $\begin{array}{l}5 \text { Years } \\
\text { or Less }\end{array}$ & $\begin{array}{l}10 \text { Years } \\
\text { or More }\end{array}$ & $\begin{array}{l}5 \text { Years } \\
\text { or Less }\end{array}$ & $\begin{array}{l}10 \text { Years } \\
\text { or More }\end{array}$ \\
\hline $\begin{array}{l}\text { No improve- } \\
\text { ment }\end{array}$ & $0 \%$ & $100 \%$ & $0 \%$ & $100 \%$ & $25 \%$ & $100 \%$ & $14 \%$ & $100 \%$ \\
\hline $\begin{array}{l}\text { Insulation } \\
\text { combined } \\
\text { (attic, wall, } \\
\text { floor) }\end{array}$ & $49 \%$ & $18 \%$ & 一 & 一 & $69 \%$ & $21 \%$ & $\cdot$ & - \\
\hline $\begin{array}{l}\text { Attic } \\
\text { insulation }\end{array}$ & - & - & $25 \%$ & $53 \%$ & - & - & $0 \%$ & $40 \%$ \\
\hline $\begin{array}{l}\text { Wall } \\
\text { Insulation }\end{array}$ & - & - & $20 \%$ & $44 \%$ & - & - & $17 \%$ & $33 \%$ \\
\hline $\begin{array}{l}\text { Floor } \\
\text { Insulation } \mathrm{E}\end{array}$ & - & - & $20 \%$ & $20 \%$ & - & 一 & NA & $50 \%$ \\
\hline $\begin{array}{l}\text { Storm wlndows/ } \\
\text { doors } \\
\text { (combined) }\end{array}$ & - & - & NA & $70 \%$ & - & - & NA & $100 \%$ \\
\hline Storm windows & $\mathrm{NA}$ & $83 \%$ & - & 一 & NA & $74 \%$ & - & - \\
\hline Storm doors & $\mathrm{NA}$ & $100 \%$ & - & - & NA & $100 \%$ & - & - \\
\hline $\begin{array}{l}\text { Caulking/ } \\
\text { weatherstripping }\end{array}$ & $20 \%$ & $50 \%$ & $30 \%$ & $54 \%$ & $25 \%$ & $31 \%$ & $32 \%$ & $21 \%$ \\
\hline $\begin{array}{l}\text { Insulate hot } \\
\text { water heater }\end{array}$ & $2 \%$ & $\begin{array}{c}0 \% \\
(N=1)\end{array}$ & $16 \%$ & $0 \%$ & 57 & $60 \%$ & $15 \%$ & $40 \%$ \\
\hline $\begin{array}{l}\text { Furnace } \\
\text { improvements }\end{array}$ & - & - & $50 \%$ & $50 \%$ & - & - & $0 \%$ & $0 \%$ \\
\hline
\end{tabular}


TABLE III-2 (continued)

\begin{tabular}{|c|c|c|c|c|c|c|c|c|c|c|}
\hline \multirow{3}{*}{$\begin{array}{l}\text { Efficlency } \\
\text { Improvements } \\
\text { Evaluated } \\
\text { by the } \\
\text { Audit }\end{array}$} & \multicolumn{5}{|c|}{ D.C. } & \multicolumn{5}{|c|}{ Denver } \\
\hline & \multicolumn{2}{|c|}{$\begin{array}{l}\text { Pre-Audit } \\
\text { Proportion } \\
\text { Identifying } \\
\text { Items with } \\
\text { Paybacks of }\end{array}$} & \multicolumn{3}{|c|}{$\begin{array}{l}\text { Post-Audit } \\
\text { Proportion } \\
\text { Identifying } \\
\text { Items with } \\
\text { Paybacks of }\end{array}$} & \multicolumn{3}{|c|}{$\begin{array}{l}\text { Pre-Audit } \\
\text { Proportion } \\
\text { Identifying } \\
\text { Items with } \\
\text { Paybacks of } \\
\end{array}$} & \multicolumn{2}{|c|}{$\begin{array}{l}\text { Post-Audit }{ }^{c} \\
\text { Proportion } \\
\text { Identifying } \\
\text { Items with } \\
\text { Paybacks of } \\
\end{array}$} \\
\hline & $\begin{array}{l}5 \text { Years } \\
\text { or Less }\end{array}$ & $\begin{array}{l}10 \text { Years } \\
\text { or More }\end{array}$ & $\begin{array}{l}5 \text { Years } \\
\text { or Less }\end{array}$ & $\begin{array}{l}10 \\
\text { or }\end{array}$ & $\begin{array}{l}\text { Years } \\
\text { More }\end{array}$ & $\begin{array}{l}5 \text { Years } \\
\text { or Less }\end{array}$ & $\begin{array}{c}10 \\
\text { or }\end{array}$ & $\begin{array}{l}\text { Years } \\
\text { More }\end{array}$ & $\begin{array}{l}5 \text { Years } \\
\text { or Less }\end{array}$ & $\begin{array}{l}10 \text { Years } \\
\text { or More }\end{array}$ \\
\hline $\begin{array}{l}\text { Clock } \\
\text { thermostat }\end{array}$ & $0 \%$ & $100 \%$ & $8 \%$ & & $67 \%$ & $0 \%$ & & $0 \%$ & $0 \%$ & $100 \%$ \\
\hline $\begin{array}{l}\text { One or more } \\
1 \text { tems }\end{array}$ & $26 \%$ & - & $33 \%$ & & - & $26 \%$ & & - & $20 \%$ & - \\
\hline
\end{tabular}

Sample Base: Audited Households in Follow-Up Survey

a. The payback for each 1 tem listed was based on audit estimates of annual energy savings divided by contractor-installed costs.

b. Pre-audit 1dentification of needed 1tems is from baseline survey question which asked what improvements could still be done (to this house) to cut down on its use of energy and make it more efficient. Up to three responses were coded. The proportions shown in the first colum are the number of households who identified the 1tem as needed out of all households for which the audit estimated that the payback would be five years or less. Proportions in second colum are number of households mentioning 1 tem out of all for whom payback was estimated to be ten years or more.

c. Post-audit 1dentification is based on (up to three) responses to follow-up survey question on what suggestions were made in the audit (see previous table for frequency of responses). Proportions in columns 1 and 2 are defined as in b. above.

1. Row shows the proportion of those who say that no 1mprovement is needed (or no aud1t suggestion recalled) out of all for whom no 1tem offered five-year payback; and proportion of those who say that no 1mprovement (suggestion) out of all units for which every 1 tem would require a ten-year or greater payback.

e. Attic, wall, and floor insulation responses on baseline survey were coded comblned.

f. Att1c, wall, and floor insulation suggestions were identffled separately in post-audit survey, but storm windows and door responses were combined.

g. The audits found no instances in both sites of either 1mprovement in storm windows or doors which would provide a payback in less than flve years. "NA" is shown for first colum figures in each site. 
responses are the efficiency improvements the household identified as needed in the baseline survey, while post audit responses are suggestions recalled from the audit. ${ }^{1}$ The degree of audit effectiveness can be judged by comparing proportions "correctly" identifying high payback items (five years or less) both before and after audit and by comparing proportions "incorrectly" identified options (with ten year payback or more). Forty-nine percent of D.C. households and 69 percent of Denver households mentioned that insulation (attic, wall, or floor) was a needed improvement out of all audited households for which this option had a five-year or less payback. Eighteen percent and twenty-one percent identified this option as needed before the audit when it had an unattractive payback. After the audit (we could separately identify each item), 65 percent (three items combined) correctly identified these items in D.C., and 17 percent correcty identified them in Denver. The proportion of households who thought these were the best payback items (when in fact payback was ten years or more) however, is much higher after the audit than before the audit.

Caulking and weatherstripping illustrates a similar result. The proportion identifying it as a high payback item increases from 20 percent to 30 percent in D.C. and from 25 percent to 32 percent in Denver. In D.C., the "error" in identifying this item as a rapid

1. This analysis replicates in part our analysis in Section III of the Phase 1 report where we identify "type 1" error--inability to identify items with five-year payback and type 2 error-identification of items with ten-year paybacks or greater. The replication was necessary because of fewer cases in the follow-up survey. Five and ten year paybacks are based on contractor-installed costs only and are used as benchmark for differentiating "most" from "least" attractive options and not as absolute criteria for investment decisions. 
payback item when it has a long payback increases from 50 to 59 percent while in Denver it decreases somewhat from 31 to 21 percent. For lowcost, frequently recommended items, particularly not water heater insulation and clock thermostats, there was only modest increases in the number of households aware that these were high payback options. "Correct" identification increase from 2 to 16 percent in D.C. and 5 to 15 percent in Denver. Clock thermostat identification increased from 0 to 8 percent in D.C. and not at all in Denver.

In summary, household knowledge of the most attractive options improves only slightly-in terms of identification of faster payback items-and appears to have worsened with respect to inappropriately identifying slow payback items. A sumary measure of any option identified (bottom of Table III-2) increased by seven percentage points in D.C. and decreased six percentage points in Denver.

The majority of households persist in mentioning the most common insulation items and storm windows as appropriate options apparently irrespective of payback. With the exception of caulking/weatherstripping, household familiarity with the attractiveness of low-cost options remains low.

Attractiveness of Efficiency Improvements Completed or Planned

Tables III-3 and 4 provide information on efficiency improvements completed since time of audit or still being planned. Table III-3 classifies all actions reported (whether or not attributed to audit) by the audit estimate of payback. Payback categories are five year or less, five to ten years, ten to 15 years, and more than 15 years (including zero estimated savings). The majority of improvements to 
TABIE III-3

PAYBACKS OF CONSERVATION IMPROVEMENTS MADE SINCE THE AUDIT ${ }^{a}$

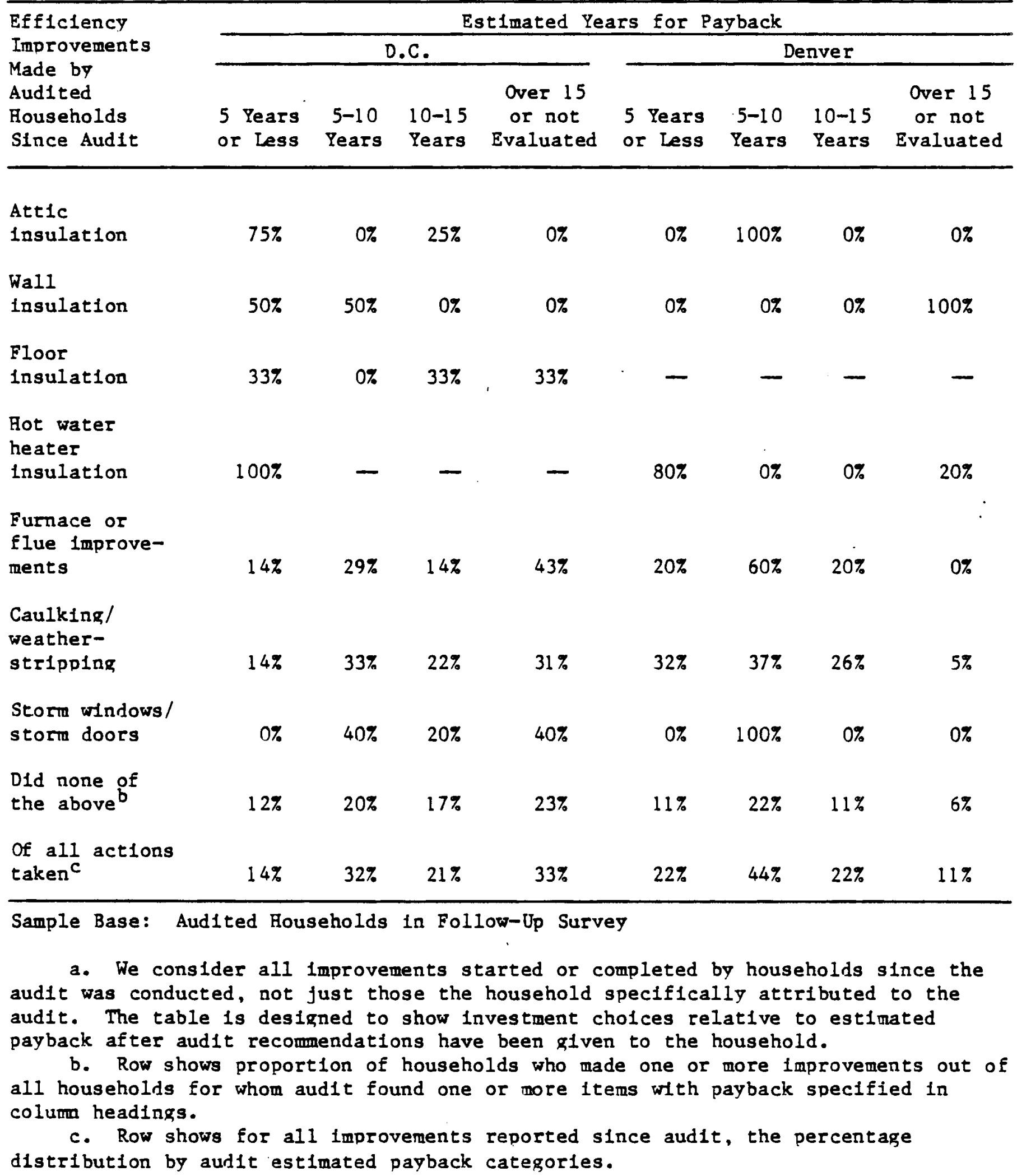


attic insulation offered only slow paybacks (less than ten years) at both sites. Significant proportions of households adding floor insulation, making furnace improvements, and adding storm windows/door performed these actions when the payback was considerably less attractive (more than ten years).

Two summary measures (at the bottom of Table III-3) provide an overall picture of the choice of activity. First, of all households for whom five years or less payback options were available (of item listed) only 12 percent did any in D.C. and only 11 percent did any in Denver. of all action taken, on ly 14 percent and 22 percent respectively were those with, the most rapid payback for the household. Thirty to 50 percent of all actions had very unattractive paybacks (more than ten years).

Table III-4 provides a summary of the incidence of attractive payback opportunities for each site. Ninety-eight percent of D.C. homes and 87 percent of Denver homes had at least one item from among the list with a five-year payback. The table also shows the proportion of households who attributed either completed or planned improvements to the audit out of all who had a five-year payback on the item. For example, 40 percent of households in each site have completed or planned caulking/weatherstripping when it offers high return. But, this is the item with the greatest response. Consistent with the analysis of all activities performed ( $T a b l e$ III-1), and despite frequent high paybacks, few ( 0 to 20 percent) households attribute action to the audit for other low-cost items, specifically water heater insulation or clock thermostats. Overall, 42 percent of D.C. households and 60 percent of Denver 
TABLE III-4

COMPLETED OR PLANNED CONSERVATION TMPROVEMENTS ATTRIB UTED

TO THE AUDIT AND RAPID PAYBACK RECOMENDATIONS

\begin{tabular}{|c|c|c|c|c|}
\hline \multirow[b]{2}{*}{$\begin{array}{l}\text { Conservation } \\
\text { Improvements } \\
\text { Evaluated by } \\
\text { the Aud1t }\end{array}$} & \multicolumn{2}{|c|}{ D.C. } & \multicolumn{2}{|c|}{ Denver } \\
\hline & $\begin{array}{l}\text { Proportion } \\
\text { of House- } \\
\text { holds with } \\
\text { Recommended } \\
\text { Improvement }\end{array}$ & $\begin{array}{l}\text { Proportion } \\
\text { Making or } \\
\text { Planning } \\
\text { Improvement } \\
\text { when } \\
\text { Recommended }\end{array}$ & $\begin{array}{l}\text { Proportion } \\
\text { of House- } \\
\text { holds with } \\
\text { Recommended } \\
\text { Improvement }\end{array}$ & $\begin{array}{l}\text { Proportion } \\
\text { Making or } \\
\text { Planning } \\
\text { Improvement } \\
\text { when } \\
\text { Recommended } b\end{array}$ \\
\hline Attic Insulation & $29 \%$ & $20 \%$ & $15 \%$ & $13 \%$ \\
\hline Wall Insulation & $21 \%$ & $0 \%$ & $11 \%$ & $0 \%$ \\
\hline Floor Insulation & $21 \%$ & $20 \%$ & - & - \\
\hline $\begin{array}{l}\text { Furnace/flue } \\
\text { Improvements }\end{array}$ & $9 \%$ & $17 \%$ & $11 \%$ & $0 \%$ \\
\hline $\begin{array}{l}\text { Water heater } \\
\text { Insulation }\end{array}$ & $91 \%$ & $7 \%$ & $36 \%$ & $5 \%$ \\
\hline $\begin{array}{l}\text { Caulking/ } \\
\text { weatherstrIpping }\end{array}$ & $14 \%$ & 407 & $46 \%$ & $40 \%$ \\
\hline Clock thermostat & $18 \%$ & $0 \%$ & $51 \%$ & $0 \%$ \\
\hline Nothing & $1 \%$ & $0 \%$ & $13 \%$ & $57 \%$ \\
\hline $\begin{array}{l}\text { Any 1tems with } \\
\text { flve-year payback }\end{array}$ & $98 \%$ & $42 \%$ & $87 \%$ & $60 \%$ \\
\hline
\end{tabular}

Sample Base: Audited Households in Follow-Up Survey

a. Proportion of audited households for which contractor-installed payback on the 1tem was estimated to be five years or less.

b. Proportion of households who attribute to the audit either having completed or planning installation of the 1tem-out of all households for whom the 1tem had payback of flve years or less (1.e., colum a proportion is base of percentage in colum b). 
households who have five-year payback options report that they have, because of the audit, completed or yet plan any such activity. 


\section{CONCLUDING COMMENTS}

This evaluation of the effectiveness of the energy audit finds modest impacts on household conservation knowledge or investment activity. While highly favorable household evaluations of the audit may make the Home Utility Audit an attractive public relations program for utility companies, audits are likely to be hard to justify on cost/benefit criteria. 1

The evaluation finds that audits may stimulate low-cost activity and may do so for otherwise less active types of households, but only with very small effects in the short run. The audit may also dampen greater conservation activity by shifting same households plans away from major retrofit.

The audit apparently does little to increase household knowledge of the most economically attractive options, however, when paybacks item for item for each household is compared to any activities completed or planned because of the audit. Overall, it is clear that the audit's effect does not approximate the optimistic projects made for it in the planning of RCS regulations (where most households were expected to install all six-year or less payback options).

We would like to be able to fully understand why audits do not significantly overcome barriers to household conservation, quicken the

1. P. Lazarre and $E$. Herst in "Evaluation of a Computerized Home Energy Audit Program in Minnesota" (mimeo) June, 1980 found audit effects on rates of activity to be in the same range as those in this study. The program they evaluated, however, was a mail self-administered audit. The program had a positive cost/benefit ratio but the project cost per participant was two dollars, not the $\$ 100$ or more spent by most utilities for an on-site audit. 
pace of investment and sharpen knowledge. Unfortunately, only several speculative explanations can be offered.

First, it is likely that economic criteria as used in the audit do not capture many or perhaps most of the calculus that households use to make retrofit decisions. Considerations of comfort (reduce draft) or aesthetic appearance, for example, may lead households to invest in storm windows and doors (despite slow payback). Households may prefer to make improvements which are more comon and familiar.

Secondly, the typical household may be unable to utilize the sophisticated payback analysis which makes up the key element of the audit. This hypothesis is supported by our previous (Phase I) analysis where we found relatively few households who could articulate the economic rational for major efficiency improvements completed in the past or planned for the future.

Thirdly, it may be necessary to incorporate a much longer time horizon to see the response to the audit. If the scenario in which young to middle age homeowners make a serial improvements to their homes over relatively long ( 5 to 15 years) time periods is correct, the audit's effect may be a more subtle iong term one. The audit suggestions may be factored into long term planning. Unfortunately, this study (and other previously) cannot capture such effects. It is clear, we believe, that audits will not provide in the short run ( 3 to 5 years) large changes in the rates of residential conservation activity. 
Appendix A

Sample Characteristics 
Baseline Sample

This. appendix provides tables showing selected socioeconomic and conservation characteristics of the household samples used in this study. The tables are structured to show comparisons relevant in assessing possible biases that might affect study results. Full details on the study design and critical sample selection procedure is provided in previously prepared reports. 1 The essential feature of the initial sample frames can be sumarized as follows: Continguous neighborhood areas were selected in D.C. and Denver, which, from Census and related material, were known to have a higher density of low- to moderate-income households, longer term residents, greater tenure stability, and older residential structures. 2 The selected areas also had a higher proportion of owner-occupied structures and a moderate proportion of multiunit structures. ${ }^{3}$ The selection procedure assured an over-sampling of elderly households (the original purpose of the study design). It also was designed to include mostly older houses of varied structure types to increase the probability of finding units with greater potential for, and which would exhibit variety in, conservation retrofits and energy efficiency improvements. Households in the baseline sample were

1. The Conservation Gap Study: Purpose, Research Design and Data Description, and Barriers to Household Investment In Residential Energy Conservation..., op. cit. Relevant referenced comparisons in all instances are the housing stock of the nation (as represented in, for instance, the National Intermim Energy Consumption Survey) and the housing stock and population of the surrounding city and SMSA from which the neighborhoods were selected.

2. The sample area included some single-family structures converted to multiunit use and some small apartment buildings. Households in structures with three or more units were screened out of the sample frame. Renters in single or two-unit structures were included. 3. See "The Elderly and the Conservation Gap" op. cit. for rationale. 
interviewed at home by our interviewer in April/May in D.C. and in July/ August in Denver. Characteristics of the baseline sample are shown in the first column for each site in Table $\mathrm{A}-1$.

\section{Follow-up Sample}

The follow-up survey was conducted in January/February 1982 by telephone. It was our intent to recontact all households in the baseline survey. Because of moves, deaths, telephone number changes and similar factors, the follow-up completion rate as a proportion of the initial sample in both sites was 79 percent in D.C. and 60 percent in Denver. (The completion rate for audited households was much higher because of a more rigorous call back procedure. See discussion below). The reason for the lower response rate in Denver is not known although interviewers reported a high proportion of telephone disconnects implying that many households had moved.

The characteristics of the follow-up sample in each site are also presented in Table A-1. These comparisons are all made on questions from the baseline survey. Some biases due to the incomplete response rate should be noted. The follow-up survey samples were slightly, but significantly, of higher socioeconomic status (as measured by income and education) than was the baseline sample. In the follow-up, there were also more households with younger members than in the baseline (and we picked up more owners in Denver).

These differences suggest that households in the follow-up sample would have higher rates of conservation activity. However, our measures of conservation effort do not give strong evidence of such a bias (middle-part of Table A-1). The number of major conservation features 
TABLE A-1

COMPARISON OF HOUSEHOLD CHARACTERISTICS:

BASELINE AND FOLLON-UP SAMPLES

\begin{tabular}{|c|c|c|c|c|}
\hline \multirow[b]{2}{*}{$\begin{array}{l}\text { Household } \\
\text { Characteristics }\end{array}$} & \multicolumn{2}{|c|}{ D.C. } & \multicolumn{2}{|c|}{ Denver } \\
\hline & $\begin{array}{l}\text { Baseline } \\
\text { Sample }\end{array}$ & $\begin{array}{l}\text { Follow-Jp } \\
\text { Sample }\end{array}$ & $\begin{array}{l}\text { Baseline } \\
\text { Sample }\end{array}$ & $\begin{array}{l}\text { Follow- Up } \\
\text { Sample }\end{array}$ \\
\hline \multicolumn{5}{|l|}{$\frac{\text { Socioeconomic }}{\text { Characteristics }}$} \\
\hline $\begin{array}{l}\text { Household Income } \\
\$ 10,000 \text { and below } \\
\$ 10,001 \text { to } \$ 15,000 \\
\text { Above } \$ 15,000\end{array}$ & $\begin{array}{l}17 \%^{* \star} \\
19 \% \\
64 \%\end{array}$ & $\begin{array}{l}13 \% \\
18 \% \\
69 \%\end{array}$ & $\begin{array}{l}29 \%^{\star \star} \\
17 \% \\
54 \%\end{array}$ & $\begin{array}{l}22 \% \\
16 \% \\
62 \%\end{array}$ \\
\hline Mean Income $(\$ 1000)$ & $24.9^{* *}$ & 26.5 & $18.7^{\star \star}$ & 20.4 \\
\hline $\begin{array}{l}\text { Level of Education } \\
\text { High school and below } \\
\text { Begond high school }\end{array}$ & $\begin{array}{l}36 \% \\
64 \%\end{array}$ & $\begin{array}{l}34 \% \\
66 \%\end{array}$ & $\begin{array}{l}52 \% \\
48 \%\end{array}$ & $\begin{array}{l}49 \% \\
51 \%\end{array}$ \\
\hline Mean years & $14.5^{*}$ & 14.6 & $12.8^{*}$ & 13.0 \\
\hline \multirow{4}{*}{$\begin{array}{l}\text { Elderly Status } \\
\text { No persons } 60 \text { years } \\
\text { old or more } \\
\text { At least on derson } 60 \\
\text { years old or more } \\
\text { and one under } 60 \\
\text { only persons } 60 \text { years } \\
\text { old or more }\end{array}$} & & & & \\
\hline & $50 \% *$ & $50 \%$ & $61 \%$ & $64 \%$ \\
\hline & $31 \%$ & $33 \%$ & $15 \%$ & $15 \%$ \\
\hline & $19 \%$ & $17 \%$ & $24 \%$ & $21 \%$ \\
\hline \multicolumn{5}{|l|}{ Tenure } \\
\hline Owners & $91 \%$ & $92 \%$ & $78 \%^{\star \star}$ & $84 \%$ \\
\hline Renters & $9 \%$ & $8 \%$ & $22 \%$ & $16 \%$ \\
\hline $\begin{array}{c}\text { Length of Tenure } \\
\text { Mean years }\end{array}$ & 17.5 & 17.8 & 12.7 & 12.6 \\
\hline \multicolumn{5}{|l|}{ Home Value } \\
\hline$\$ 80,000$ and below & $77 \%$ & $76 \%$ & $87 \%$ & $86 \%$ \\
\hline Above $\$ 80,000$ & $23 \%$ & $24 \%$ & $13 \%$ & $14 \%$ \\
\hline Mean value $(\$ 1000)$ & $\$ 70.3$ & $\$ 71.4$ & $\$ 67.2$ & $\% 67.0$ \\
\hline
\end{tabular}


TABLE A-1 (continued)

\begin{tabular}{|c|c|c|c|c|}
\hline \multirow[b]{2}{*}{$\begin{array}{c}\text { Household } \\
\text { Characteristics }\end{array}$} & \multicolumn{2}{|c|}{ D.C. } & \multicolumn{2}{|c|}{ Denver } \\
\hline & $\begin{array}{l}\text { Baseline } \\
\text { Sample }\end{array}$ & $\begin{array}{c}\text { Follow-Up } \\
\text { Sample }\end{array}$ & $\begin{array}{c}\text { Baseline } \\
\text { Sample }\end{array}$ & $\begin{array}{c}\text { Follow-Up } \\
\text { Sample }\end{array}$ \\
\hline
\end{tabular}

Conservation

Characterlstics

Number of Major

Features in Place d

0 or 1 major 1 tem

2 major 1 tems

3 or 4 major 1 tems

$13 \%^{*}$

Mean number of major items

Number of Major Conservation Items Installed by

the Current Residents

0 or 1 major 1 tem

2 or 3 major 1 tems

4 major 1tems

Mean number of

major 1 tems

Installing Major Conservation Items within

Last Two Years

Reporting Any Additional

Efficiency Improvements

Reporting Any Curtallment of Energy Use

Mean Proportion of Mafor

Features in Place

Installed by the Current

Residents $d$

Identifying as Needed

One or More Additional

Efficiency Improvements

Planning to Install

a Mafor Efficiency

Improverent before

Next Winter
$31 \%$

$56 \%$

$12 \%$

$28 \%$

$60 \%$

$2.6^{\star *}$

2.7

$2.4^{\star *}$

2.5

$47 \%$

$45 \%$

$8 \%$

$45 \%$

$47 \%$

$8 \%$

$63 \%$

$35 \%$

27

$62 \%$

$35 \%$

37

1.7

1.7

1.1

1.2

$16 \%$

$17 \%$

$25 \%^{\star \star}$

$29 \%$

$65 \%$

$64 \%$

$66 \%^{\star}$

$70 \%$

$68 \%$

$68 \%$

$77 \%$

$76 \%$

.61

.61

.40

.39

$76 \%$

$74 \%$

$74 \%^{*}$

$78 \%$

$24 \%$

$9 \%$

5

\section{$\%$}

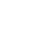


TABLE A-1 (continued)

\begin{tabular}{|c|c|c|c|c|}
\hline \multirow[b]{2}{*}{$\begin{array}{l}\text { Household } \\
\text { Characteristics }\end{array}$} & \multicolumn{2}{|c|}{ D.C. } & \multicolumn{2}{|c|}{ Denver } \\
\hline & $\begin{array}{l}\text { Baseline } \\
\text { Sample }\end{array}$ & $\begin{array}{l}\text { Follow-Up } \\
\text { Sample }\end{array}$ & $\begin{array}{l}\text { Baseline } \\
\text { Sample }\end{array}$ & $\begin{array}{c}\text { Follow-Up } \\
\text { Sample }\end{array}$ \\
\hline $\begin{array}{l}\text { Important Reasons for } \\
\text { Not Making Addit1onal } \\
\text { Efflclency Improvements }\end{array}$ & & & & \\
\hline $\begin{array}{l}\text { Reporting They Were } \\
\text { Not Sure of What } \\
\text { Improvements to Make }\end{array}$ & $26 \%$ & $27 \%$ & $35 \%$ & $38 \%$ \\
\hline $\begin{array}{l}\text { Reporting They Felt that } \\
\text { Additlonal Improvements } \\
\text { Would Not Save Enough } \\
\text { Money or Energy }\end{array}$ & $43 \%$ & $42 \%$ & $40 \%$ & $40 \%$ \\
\hline $\begin{array}{l}\text { Reporting They Could Not } \\
\text { Afford Energy-Saving } \\
\text { Improvements Without a } \\
\text { Loan }\end{array}$ & $53 \%$ & $52 \%$ & $55 \%$ & $56 \%$ \\
\hline $\begin{array}{l}\text { Reporting The1r Home Did } \\
\text { Not Need Any Energy- } \\
\text { Saving Improvements }\end{array}$ & - & - & $43 \%$ & $44 \%$ \\
\hline $\begin{array}{l}\text { Reporting They Believed } \\
\text { Moderate to Substantial } \\
\text { Savings Were Possible by } \\
\text { Cutting Back on } \\
\text { Energy Use }\end{array}$ & $31 \%$ & $33 \%$ & $18 \%$ & $16 \%$ \\
\hline $\begin{array}{l}\text { Reporting They Belleved } \\
\text { Moderate to Substantial } \\
\text { Savings Were Possible by } \\
\text { Installing Emergy Con- } \\
\text { servation Items }\end{array}$ & $52 \%$ & $54 \%$ & $44 \%$ & $46 \%$ \\
\hline
\end{tabular}

** Indicates significant difference at .05 in percentage

distribution between baseline sample and follow-up sample.

* Indicates significant difference at .1 .

a. Baseline sample slzes are 277 households in D.C. and 354 households in Denver.

b. Follow-up sample sizes are 218 households in D.C. and 209 households in Denver.

c. Education is for most educated member of household.

d. Major weatherization features include four items: attic and wall insulation, storm windows, and storm doors. 
"ever installed," the proportion installed by current residents, and reported efforts to curtail energy use are not significantly different in the baseline and follow-up samples. The number of major features in place, however, is slightly higher in the follow-up sample; the number of recent actions and reported additional efficiency improvements (as reported in baseline questionnaire) is greater among the follow-up in Denver. In Denver, there is also a greater proportion of households in the follow-up who prior to the audit, could identify and/or said they planned conservation improvements (five percentage points).

In comparing reasons cited as important for not making additional conservation investments and attitudes which measure conservation predisposition (believe potential savings from retrofit and curtailment of use are large) there are slight, but insignificant differences between the pre- and post-audit samples.

\section{Post-Audit Control Sample}

At the time of the follow-up survey, we also selected and contacted by phone, small control samples at each site. Sample households were drawn from the list of addresses from the original baseline but included only households not previously contacted. Thus, except for the difference in interview technique (phone versus at home) these samples represent, in principle, a second random selection from among the neighborhood populations.

The selection of a control sample had limited purpose. The principal analytic focus of this report is the observed differences in rates of activity between audited and unaudited households. Because our interviewers discussed and queried households with an extensive list of 
energy related topics during an initial 45 minutes interview in the home of respondents, both audited and unaudited household conservation effort may have been altered by our interview process. The control group was designed as a benchmark against which conservation activity of the follow-up sample could be compared.

Table A-2 provide a comparison of basic household characteristics of the follow-up samples (subsets of baseline samples) and the control samples at both sites. The characteristics compared are those measured during the first interview with the follow-up (baseline sample). Household income and homeownership distributions are quite similar in the follow-up and control samples. However, there are marked differences in the age composition between the two samples with the control samples having greater proportion of elderly households. Average tenure duration is also longer in the control sample.

Some conservation and attitude characteristics which we have identified with elderly households are also evident although not all conservation related attributes differ between samples. 1 The status of the unit-as measured by average number of major features in place--does not significantly differ between samples. However, the proportion of features present that were installed by current resident is slightly higher in the control samples (consistent with longer tenure duration).

The greater differences in the control sample are with respect to low-cost actions, identified and planned improvements and attitudes which indicate predisposition toward conservation. As a consequence of

1. These factors were identified in "The Elderly and the Conservation Gap" op. cit. 
TABLE $A-2$

COMPARISON OF HOUSEHOLD CHARACTERISTICS:

FOLLOW-UP AND POST-CONTROL SAMPLES

\begin{tabular}{|c|c|c|c|c|}
\hline \multirow[b]{2}{*}{$\begin{array}{l}\text { Household } \\
\text { Characteristics }\end{array}$} & \multicolumn{2}{|c|}{ D.C. } & \multicolumn{2}{|c|}{ Denver } \\
\hline & $\begin{array}{l}\text { Follow-Up } \\
\text { Sample }\end{array}$ & $\begin{array}{l}\text { Control } \\
\text { Sample }\end{array}$ & $\begin{array}{c}\text { Follow-Up } \\
\text { Sample }\end{array}$ & $\begin{array}{l}\text { Control } \\
\text { Sample }\end{array}$ \\
\hline \multicolumn{5}{|l|}{$\begin{array}{l}\text { Socloeconomic } \\
\text { Characteristles }\end{array}$} \\
\hline $\begin{array}{l}\text { Household Income } \\
\qquad 10,000 \text { and below } \\
\$ 10,001 \text { to } \$ 15,000 \\
\text { Above } \$ 15,000\end{array}$ & $\begin{array}{l}13 \% \\
18 \% \\
69 \%\end{array}$ & $\begin{array}{l}13 \% \\
17 \% \\
70 \%\end{array}$ & $\begin{array}{l}22 \% \\
16 \% \\
62 \%\end{array}$ & $\begin{array}{l}14 \% \\
31 \% \\
55 \%\end{array}$ \\
\hline Mean Income $(\$ 1000)$ & 26.5 & 25.2 & 20.4 & 20.4 \\
\hline \\
\hline $\begin{array}{l}\text { old or more } \\
\text { At least on person } 60 \\
\text { years old or more }\end{array}$ & $51 \%$ & $44 \%$ & $64 \%$ & $42 \%$ \\
\hline $\begin{array}{l}\text { and one under } 60 \\
\text { only persons } 60 \text { years }\end{array}$ & $33 \%$ & $27 \%$ & $15 \%$ & $16 \%$ \\
\hline old or more & $16 \%$ & $29 \%$ & $21 \%$ & $42 \%$ \\
\hline \multicolumn{5}{|l|}{ Tenure } \\
\hline $\begin{array}{l}\text { Owners } \\
\text { Renters }\end{array}$ & $\begin{array}{r}92 \% \\
8 \%\end{array}$ & $\begin{array}{r}927 \\
8 \%\end{array}$ & $\begin{array}{l}84 \% \\
16 \%\end{array}$ & $\begin{array}{l}82 \% \\
18 \%\end{array}$ \\
\hline $\begin{array}{c}\text { Length of Tenure } \\
\text { Mean years }\end{array}$ & 17.8 & 21.2 & 12.6 & 15.4 \\
\hline $\begin{array}{l}\text { Home Value } \\
\$ 80,000 \text { and below } \\
\text { Above } \$ 80,000\end{array}$ & $\begin{array}{l}76 \% \\
24 \%\end{array}$ & $\begin{array}{l}56 \% \\
44 \%\end{array}$ & $\begin{array}{l}86 \% \\
14 \%\end{array}$ & $\begin{array}{l}82 \% \\
18 \%\end{array}$ \\
\hline Mean value $(\$ 1000)$ & $\$ 71.8$ & $\$ 89.0$ & $\$ 67.0$ & 71.1 \\
\hline \multicolumn{5}{|l|}{$\begin{array}{l}\text { Conservation } \\
\text { Characterist1cs }\end{array}$} \\
\hline \multicolumn{5}{|l|}{$\begin{array}{l}\text { Number of Major } \\
\text { Features in Place }\end{array}$} \\
\hline $\begin{array}{l}0 \text { or } 1 \text { major } 1 \text { tem } \\
2 \text { major } 1 \text { tems }\end{array}$ & $\begin{array}{l}12 \% \\
28 \%\end{array}$ & $\begin{array}{r}9 \% \\
28 \%\end{array}$ & $\begin{array}{l}17 \% \\
24 \%\end{array}$ & $\begin{array}{l}21 \% \\
17 \%\end{array}$ \\
\hline 3 or 4 mator items & $60 \%$ & $63 \%$ & $59 \%$ & $62 \%$ \\
\hline $\begin{array}{l}\text { Mean number of } \\
\text { major items }\end{array}$ & 2.7 & 2.7 & 2.5 & 2.5 \\
\hline
\end{tabular}


TABLE A-2 (continued)

\begin{tabular}{|c|c|c|c|c|}
\hline \multirow[b]{2}{*}{$\begin{array}{l}\text { Household } \\
\text { Characteristics }\end{array}$} & \multicolumn{2}{|c|}{ D.C. } & \multicolumn{2}{|c|}{ Denver } \\
\hline & $\begin{array}{l}\text { Follow-Up } \\
\text { Sample }\end{array}$ & $\begin{array}{l}\text { Control } \\
\text { Sample }\end{array}$ & $\begin{array}{l}\text { Follow-Up } \\
\text { Sample }\end{array}$ & $\begin{array}{l}\text { Control } \\
\text { Sample }\end{array}$ \\
\hline $\begin{array}{l}\text { Number of Mafor Conserva- } \\
\text { tion Items Installed by } \\
\text { the Current Residents }\end{array}$ & & & & \\
\hline 0 or 1 major item & $45 \%$ & $28 \%$ & $62 \%$ & $59 \%$ \\
\hline 2 or 3 mator items & $47 \%$ & $65 \%$ & $35 \%$ & $38 \%$ \\
\hline 4 major items & $8 \%$ & $7 \%$ & $3 \%$ & $3 \%$ \\
\hline $\begin{array}{c}\text { Mean number of } \\
\text { major items }\end{array}$ & 1.7 & 2.0 & 1.2 & 1.2 \\
\hline $\begin{array}{l}\text { Installing Major Con- } \\
\text { servation Items within } \\
\text { Last Two Years }\end{array}$ & $17 \%$ & $24 \%$ & $29 \%$ & $37 \%$ \\
\hline $\begin{array}{l}\text { Reporting Any Additional } \\
\text { Efflclency Improvements }\end{array}$ & $64 \%$ & $48 \%$ & $70 \%$ & $13 \%$ \\
\hline $\begin{array}{l}\text { Reporting Any Curtallment } \\
\text { of Energy Use }\end{array}$ & $68 \%$ & $55 \%$ & $76 \%$ & $54 \%$ \\
\hline $\begin{array}{l}\text { Mean Proportion of Mator } \\
\text { Features in Place } \\
\text { Installed by the Current } \\
\text { Residents }\end{array}$ & .61 & .68 & .39 & .43 \\
\hline $\begin{array}{l}\text { Identifying as Needed } \\
\text { One or More Add1t1onal } \\
\text { Efficlency Improvements }\end{array}$ & $71 \%$ & $54 \%$ & $78 \%$ & $29 \%$ \\
\hline $\begin{array}{l}\text { Planning to Install } \\
\text { a Major Efficlency } \\
\text { Improvement before } \\
\text { Next Winter }\end{array}$ & $54 \%$ & $43 \%$ & $46 \%$ & $52 \%$ \\
\hline$\frac{\frac{\text { Important Reasons for }}{\text { Not Mak1ng Add1tional }}}{\text { Efflclency Improvements }}$ & & & & \\
\hline $\begin{array}{l}\text { Reporting They Were } \\
\text { Not Sure of What } \\
\text { Improvements to Make }\end{array}$ & $27 \%$ & $36 \%$ & $38 \%$ & $43 \%$ \\
\hline
\end{tabular}


TABLE A-2 (continued)

\begin{tabular}{|c|c|c|c|c|}
\hline \multirow[b]{2}{*}{$\begin{array}{l}\text { Household } \\
\text { Characteristics }\end{array}$} & \multicolumn{2}{|c|}{ D.C. } & \multicolumn{2}{|c|}{ Denver } \\
\hline & $\begin{array}{c}\text { Follow-Up } \\
\text { Sample }\end{array}$ & $\begin{array}{l}\text { Control } \\
\text { Sample }\end{array}$ & $\begin{array}{l}\text { Follow-Up } \\
\text { Sample }\end{array}$ & $\begin{array}{l}\text { Control } \\
\text { Sample }\end{array}$ \\
\hline $\begin{array}{l}\text { Reporting They Felt that } \\
\text { Additional Improvements } \\
\text { Would Not Save Enough } \\
\text { Money or Energy }\end{array}$ & $42 \%$ & $39 \%$ & $40 \%$ & $52 \%$ \\
\hline $\begin{array}{l}\text { Reporting They Could Not } \\
\text { Afford Energy-Saving } \\
\text { Improvements Without a } \\
\text { Loan }\end{array}$ & $52 \%$ & $45 \%$ & $56 \%$ & $49 \%$ \\
\hline $\begin{array}{l}\text { Reporting Their Home Did } \\
\text { Not Need Any Energy- } \\
\text { Saving Improvements }\end{array}$ & - & $46 \%$ & $44 \%$ & $57 \%$ \\
\hline $\begin{array}{l}\text { Reporting They Believed } \\
\text { Moderate to Substantial } \\
\text { Savings Were Possible by } \\
\text { Cutting Back on } \\
\text { Energy Use }\end{array}$ & $33 \%$ & $30 \%$ & $16 \%$ & $27 \%$ \\
\hline $\begin{array}{l}\text { Reporting They Believed } \\
\text { Moderate to Substantial } \\
\text { Savings Were Possible by } \\
\text { Installing Energy Con- } \\
\text { servation Items }\end{array}$ & $54 \%$ & $47 \%$ & $46 \%$ & $40 \%$ \\
\hline
\end{tabular}

a. The Follow-Up Sample included all households in original baseline survey. Response rate to follow-up survey was 76 percent in D.C. and 60 percent in Denver resulting in an " $N "$ of 218 and 209 respectively for the two sites.

b. The Control Sample was surveyed at the same time the follow-up survey was conducted. Sample size for each site was 100 households. Households were selected at random from among previously uncontacted households in site areas as defined for baseline survey. 
this bias in the control sample, it does not well suit the initial purpose for which it was selected. While most of these differences may not be statistically significant (i.e., suggest the samples are from different populations) they nevertheless indicate a predisposition toward less conservation activity among the control groups. The explanation for this difference is the greater number of elderly and longer term residents we obtained in the control sample.

As a consequence of this bias, we have relied little on control sample comparisons in the body of this report. We have instead added analysis (in Section II) which introduces controls for some of these predispositions measures (e.g., planned activity) for the unaudited and audited follow-up samples. However, we cannot say for certain that rates of activity in both audited and unaudited follow-up samples were not stimulated in part by pre-audit interviewing.

\section{Audited Samples}

Table A-3 provides a comparison of characteristics of the audited samples. There were a total of 85 and 91 households audited in D.C. and Denver respectively. The response rates to the follow-up surveys for these groups were 92 percent and 85 percent respectively resulting in a follow-up sample of 79 and 77 households. 1

The follow-up samples of audited households have slightly higher incomes and education (mostly insignificant). Elderly status is not

1. These sample sizes are those used in Sections I and II of the report which compare activities of audited and unaudited households. However, because the utilities did not transfer to us copies of audit reports of all households audited, we have audit pay back data (as presented in Section III) on only 70 and 55 households respectively in D.C. and Denver. 
TABLE A-3

CHARACTERISTICS OF AUDITED HOUSEHOLDS:

BASELINE AND FOLLOW-UP SURVEYS

\begin{tabular}{|c|c|c|c|c|}
\hline \multirow[b]{2}{*}{$\begin{array}{l}\text { Household } \\
\text { Characteristics }\end{array}$} & \multicolumn{2}{|c|}{ D.C. } & \multicolumn{2}{|c|}{ Denver } \\
\hline & $\begin{array}{c}\text { Audited } \\
\text { Subs ample }\end{array}$ & $\begin{array}{l}\text { Follow-Up } \\
\text { Sample }\end{array}$ & $\begin{array}{c}\text { Audited } \\
\text { Subsample }\end{array}$ & $\begin{array}{l}\text { Follow-Up } \\
\text { Sample }\end{array}$ \\
\hline$\frac{\text { Socloeconomic }}{\text { Characteristics }}$ & & & & \\
\hline $\begin{array}{l}\text { Household Income } \\
\$ 10,000 \text { and below } \\
\$ 10,001 \text { to } \$ 15,000 \\
\text { Above } \$ 15,000\end{array}$ & $\begin{array}{l}15 \% \\
11 \% \\
74 \%\end{array}$ & $\begin{array}{l}15 \% \\
10 \% \\
75 \%\end{array}$ & $\begin{array}{l}29 \% \\
14 \% \\
57 \%\end{array}$ & $\begin{array}{l}27 \% \\
13 \% \\
60 \%\end{array}$ \\
\hline Mean Income $(\$ 1000)$ & 27.1 & 27.6 & 18.7 & 19.2 \\
\hline $\begin{array}{l}\text { Level of Education }{ }^{c} \\
\text { High school and below } \\
\text { Beyond high school }\end{array}$ & $\begin{array}{l}23 \% \\
77 \%\end{array}$ & $\begin{array}{l}22 \% \\
78 \%\end{array}$ & $\begin{array}{l}62 \% \\
38 \%\end{array}$ & $\begin{array}{l}62 \% \\
38 \%\end{array}$ \\
\hline Mean years & $15.1^{*}$ & 15.3 & 12.9 & 12.8 \\
\hline $\begin{array}{l}\text { Elderly Status } \\
\text { No persons } 60 \text { years }\end{array}$ & . & & & \\
\hline $\begin{array}{l}\text { old or more } \\
\text { At least on person } 60 \\
\text { years old or more }\end{array}$ & $47 \%$ & $47 \%$ & $64 \%$ & $62 \%$ \\
\hline $\begin{array}{l}\text { and one under } 60 \\
\text { only persons } 60 \text { years }\end{array}$ & $34 \%$ & $35 \%$ & $19 \%$ & $20 \%$ \\
\hline old or more & $19 \%$ & $18 \%$ & $17 \%$ & $18 \%$ \\
\hline Tenure & & & & \\
\hline $\begin{array}{l}\text { Owners } \\
\text { Renters }\end{array}$ & $\begin{array}{r}93 \% \\
7 \%\end{array}$ & $\begin{array}{r}93 \% \\
7 \%\end{array}$ & $\begin{array}{l}75 \% \\
25 \%\end{array}$ & $\begin{array}{l}82 \% \\
18 \%\end{array}$ \\
\hline $\begin{array}{c}\text { Length of Tenure } \\
\text { Mean years }\end{array}$ & 15.8 & 16.3 & 11.0 & 11.6 \\
\hline $\begin{array}{l}\text { Home Value } \\
\$ 80,000 \text { and below } \\
\text { Above } \$ 80,000\end{array}$ & $\begin{array}{l}69 \% \\
31 \%\end{array}$ & $\begin{array}{l}66 \% \\
34 \%\end{array}$ & $\begin{array}{l}87 \% \\
13 \%\end{array}$ & $\begin{array}{l}87 \% \\
13 \%\end{array}$ \\
\hline Mean value $(\$ 1000)$ & $\$ 7.4 .8^{*}$ & $\$ 76.4$ & $\$ 65.9$ & $\$ 65.3$ \\
\hline
\end{tabular}


TABLE A-3 (continued)

\begin{tabular}{|c|c|c|c|c|}
\hline \multirow[b]{2}{*}{$\begin{array}{l}\text { Household } \\
\text { Characteristics }\end{array}$} & \multicolumn{2}{|c|}{ D.C. } & \multicolumn{2}{|c|}{ Denver } \\
\hline & $\begin{array}{c}\text { Aud 1ted } \\
\text { Subs amp le }\end{array}$ & $\begin{array}{l}\text { Follow-Up } \\
\text { Sample }\end{array}$ & $\begin{array}{c}\text { Aud1ted } \\
\text { Subsample }\end{array}$ & $\begin{array}{l}\text { Follow-Up } \\
\text { Sample }\end{array}$ \\
\hline$\frac{\text { Conservation }}{\text { Characteristics }}$ & & & & \\
\hline $\begin{array}{l}\text { Number of Mafor } \\
\text { Features in Place }\end{array}$ & & & & \\
\hline $\begin{array}{l}0 \text { or } 1 \text { major item } \\
2 \text { major items } \\
3 \text { or } 4 \text { major items }\end{array}$ & $\begin{array}{r}9 \% \\
33 \% \\
58 \%\end{array}$ & $\begin{array}{l}10 \% \\
30 \% \\
60 \%\end{array}$ & $\begin{array}{l}22 \% \\
26 \% \\
52 \%\end{array}$ & $\begin{array}{l}18 \% \\
24 \% \\
58 \%\end{array}$ \\
\hline $\begin{array}{l}\text { Mean number of } \\
\text { major 1tems }\end{array}$ & 2.6 & 2.7 & $2.3^{\star \star}$ & 2.5 \\
\hline $\begin{array}{l}\text { Number of Mafor Conserva- } \\
\text { tion Items Installed by } \\
\text { the Current Residents }\end{array}$ & & & & \\
\hline 0 or 1 major item & $49 \%$ & $48 \%$ & $67 \%$ & $67 \%$ \\
\hline 2 or 3 major items & $46 \%$ & $46 \%$ & $32 \%$ & $31 \%$ \\
\hline 4 major 1 tems & $5 \%$ & $6 \%$ & $1 \%$ & $2 \%$ \\
\hline $\begin{array}{l}\text { Mean number of } \\
\text { major items }\end{array}$ & 1.5 & 1.5 & 1.0 & 1.0 \\
\hline $\begin{array}{l}\text { Installing Major Con- } \\
\text { servation Items within } \\
\text { Last Two Years }\end{array}$ & $21 \%$ & $21 \%$ & $32 \%$ & $33 \%$ \\
\hline $\begin{array}{l}\text { Reporting Any Additional } \\
\text { Efflclency Improvements }\end{array}$ & $67 \%$ & $67 \%$ & $67 \%$ & $69 \%$ \\
\hline $\begin{array}{l}\text { Reporting Any Curtallment } \\
\text { of Energy Use }\end{array}$ & $78 \%$ & $79 \%$ & $78 \%$ & $82 \%$ \\
\hline $\begin{array}{l}\text { Mean Proportion of Mafor } \\
\text { Features in Place } \\
\text { Installed by the Current } \\
\text { Residents }\end{array}$ & .58 & .57 & .35 & .34 \\
\hline $\begin{array}{l}\text { Identifying as Needed } \\
\text { One or More Additional } \\
\text { Efficiency Improverents }\end{array}$ & $79 \%$ & $79 \%$ & $90 \%$ & $91 \%$ \\
\hline $\begin{array}{l}\text { Planning to Install } \\
\text { a Major Efficlency } \\
\text { Improvement before } \\
\text { Next Winter }\end{array}$ & $57 \%$ & $57 \%$ & $48 \%$ & $49 \%$ \\
\hline
\end{tabular}


TABLE A-3 (continued)

\begin{tabular}{|c|c|c|c|c|}
\hline \multirow[b]{2}{*}{$\begin{array}{l}\text { Household } \\
\text { Characteristics }\end{array}$} & \multicolumn{2}{|c|}{ D.C. } & \multicolumn{2}{|c|}{ Denver } \\
\hline & $\begin{array}{c}\text { Aud1ted } \\
\text { Subs ample }\end{array}$ & $\begin{array}{l}\text { Follow-Up } \\
\text { Sample }\end{array}$ & $\begin{array}{c}\text { Audited } \\
\text { Subs ample } e^{a}\end{array}$ & $\begin{array}{l}\text { Follow-Up } \\
\text { Sample }\end{array}$ \\
\hline
\end{tabular}

Important Reasons for

Not Making Additional

Efflclency Improvements

Reporting They Were

Not Sure of What

Improvements to Make

$30 \%$

$29 \%$

$42 \%$

$42 \%$

Reporting They Felt that

Additional Improvements

Would Not Save Enough

Money or Energy

$43 \%$

$43 \%$

$42 \%$

$44 \%$

Reporting They Could Not

Afford Energy-Saving

Improvements Without a

Loan

$51 \%$

$51 \%$

$57 \%$

$58 \%$

Reporting They Belleved

Moderate to Substantial

Savings Were Possible by

Cutting Back on

Energy Use

$32 \%$

$35 \%$

$19 \%$

$16 \%$

Reporting They Belleved Moderate to Substantial Savings Were Possible by Installing Energy Conservation Items $56 \%$ $55 \%$

$54 \%$

$52 \%$

** Indicates signiflcant difference at .05 in percentage

distribution between audited households in baseline survey and those in follow-up survey.

* Indicates significant difference at .1 .

a. Baseline survey included 85 audited households in D.C. and 91 audited households in Denver.

b. Follow-up survey response rates were 92 percent and 85 percent respectively, resulting in follow-up sample sizes for audited households of 79 in D.C. and 77 in Denver.

c. Education is for most educated member of household.

d. Mafor weatherization features include four 1tems: attic and

wall insulation, storm windows, and storm doors. 
significantly different. We have picked up more homeowners in Denver than in the original audit sample. Length of tenure and estimated home value do not significantly differ between initial and follow-up samples. Follow-up sample households were slightly more likely to have been active and to have more features in place prior to audit. Planned activity (prior to audit), reasons cited for making further investments, and belief in the potential savings from conservation do not consistently or significantly differ between the full audited samples and audited households in the follow-up surveys.

Sumary of Sample Bias Effects on Study Results

On the basis of information in this appendix and information documented previously we can suggest biases that may affect this study's assessment of audit impact. First we find no significant bias to the less than 100 percent response rate achieved in the follow-up survey for audited households. Those we were able to recontact in our follow-up survey are similar to the full sample on most essential characteristics. The higher rate of homeownership indicates that we probably have a slight over-estimate of activity in response to the audit than that in the full sample, since homeowners are known to make more conservation improvements than renters. However, this bias is not significant in light of the study's basic conclusions.

In our Phase I report, we documented the differences between audited households and other households in our baseline survey. 1

1. See "Sample Bias in Characteristics of Households Receiving Audits" (pp. 50-52) in Section IV of Barriers to Household Investment in Residential Energy Conservation... op. cit. 
Characteristics of audited households differed from unaudited households for two reasons: self-selection (those willing to sign a report for a free audit) and procedural selection. Both The Urban Institute and the utility companies conducting audits followed scheduled and other procedures which tended to exclude some households. The net impact of these two factors was an audit sample of slightly higher socioeconomic status, households who were more likely to believe that substantial energy savings are possible from improved weatherization, and who were planning (some) additional improvement for the near future. The audited sample did not, however, significantly differ from the unaudited sample in terms of past conservation actions. In addition, the major reasons cited for not taking action were similar in both samples.

The bias implied in our audited sample, then is that prior to the audit, because of socioeconomic status and plans, audited households would be more predisposed to making conservation improvements than unaudited households. Similarly, because of the slightly higher (yet) socioeconomic status and homeownership in the follow-up, the post audit rates of activity are likely to be over- rather than underestimated. Despite these tendencies, we found little evidence as presented in the analysis of this report for attributing significant conservation activity or knowledge to the energy audit. 


\section{DISTRIBUTION}

No. of

Copies

OFFSITE

27 DOE Technical Information

Center

5 Wayne Hoffman

National Institute for

Social \& Economic Research

Boulder, CO 80302

1 JN Franke

Bonneville Power Administration

Portland, OR 97208

1 Peter Back

Department of Energy

Washington, DC 20585

\section{ONSITE}

DOE Richland Operations Office

H. E. Ransom

65 Pacific Northwest Laboratory

WB Ashton (1)

Economics Library (2)

AL Nieves (54)

RG Rivera (1)

Publishing Coordination (2)

Technical Information (5) 